Article

\title{
CoFe/SBA-15 catalyst coupled with peroxymonosulfate for heterogeneous catalytic degradation of rhodamine $B$ in water
}

\author{
Longxing $\mathrm{Hu}^{*}$, Fan Yang, Lianpei Zou, Hang Yuan, Xing $\mathrm{Hu}$ \\ School of Environmental and Chemical Engineering, Shanghai University, Shanghai 2000444, China
}

\section{A R T I C L E I N F O}

Article history:

Received 18 May 2015

Accepted 17 June 2015

Published 20 October 2015

\section{Keywords:}

Cobalt

Iron

SBA-15

Peroxymonosulphate

Rhodamine B degradation

Advanced oxidation technologies

Sulfate radical

\begin{abstract}
A B S T R A C T
CoFe/SBA-15 catalysts were prepared by simultaneous incipient wetness impregnation using $\mathrm{Co}\left(\mathrm{NO}_{3}\right)_{2} \cdot 6 \mathrm{H}_{2} \mathrm{O}$ and $\mathrm{Fe}\left(\mathrm{NO}_{3}\right)_{3} \cdot 9 \mathrm{H}_{2} \mathrm{O}$ as the precursors and SBA-15 as the support. The catalysts were used to activate generation of sulfate radicals from peroxymonosulfate (PMS) for rhodamine $\mathrm{B}(\mathrm{RhB})$ dye degradation in aqueous solutions. The catalyst was characterized using X-ray diffraction, $\mathrm{N}_{2}$ adsorption-desorption, scanning electron microscopy and energy-dispersive X-ray spectroscopy, transmission electron microscopy, and vibrating sample magnetometry. The effects of the Co and Fe loadings and calcination temperature on the catalytic performance, catalyst reusability, and kinetics and mechanism of catalytic oxidative degradation of $\mathrm{RhB}$ in the presence of $\mathrm{CoFe} / \mathrm{SBA}-15$ and PMS were investigated. The results show that the predominant Co-Fe oxide loaded on the support was the composite $\mathrm{CoFe}_{2} \mathrm{O}_{4}$, which provided the active catalytic sites, and was present in the SBA-15 matrix. The surface area, pore volume, and mean pore diameter of 10Co9.5Fe/SBA-15-700 were $506.1 \mathrm{~m}^{2} / \mathrm{g}, 0.669 \mathrm{~cm}^{3} / \mathrm{g}$, and $7.4 \mathrm{~nm}$, respectively, lower than those of SBA-15. 10Co9.5Fe/SBA-15-700 consisted of rod-like aggregates with diameters greater than $0.25 \mu \mathrm{m}$. It had a magnetic intensity of $8.3 \mathrm{emu} / \mathrm{g}$; therefore, magnetic separation was feasible. 10 Co9.5Fe/SBA-15-700 showed good catalytic activity and stability, with a RhB degradation rate higher than $96 \%$ and Co leaching lower than $32.4 \mu \mathrm{g} / \mathrm{L}$. The catalytic oxidative degradation of $\mathrm{RhB}$ in the presence of FeCo/SBA-15 and PMS obeyed first-order kinetics, and the degradation rate increased with increasing CoFe/SBA-15 and PMS dosages and with decreasing initial reactant concentrations. Quenching tests showed that sulfate radicals played a dominant role in $\mathrm{RhB}$ catalysis. CoFe/SBA-15 maintained high catalytic activity and good stability during 10 recycling runs, with a RhB degradation rate greater than $84 \%$, Co and Fe leaching for each run lower than 72.1 and $35 \mu \mathrm{g} / \mathrm{L}$, respectively. CoFe/SBA-15 is an efficient catalyst for PMS oxidation, and has potential applications in the removal of refractory organics such as $\mathrm{RhB}$ in water.
\end{abstract}

(C) 2015, Dalian Institute of Chemical Physics, Chinese Academy of Sciences. Published by Elsevier B.V. All rights reserved.

\section{Introduction}

Advanced oxidation techniques are innovative water and wastewater treatment methods based on the in situ generation of highly reactive radicals such as $\mathrm{OH} \cdot \mathrm{O}_{2}{ }^{--}, \mathrm{OOH}^{*}$, and $\mathrm{SO}_{4}{ }^{-}$ (sulfate radical). They are used for degradation and mineraliza- tion of refractory organic pollutants [1-5]. In the last decade, sulfate-radical-based advanced oxidation techniques have received much attention for environmental applications, because at neutral $\mathrm{pH} \mathrm{SO}_{4}{ }^{--}$is a powerful and selective oxidant for the decomposition of organic pollutants, and its use avoids some of the disadvantages of conventional Fenton processes $[3,6,7]$.

* Corresponding author. Tel/Fax:+86-21-66137771; E-mail: hulxhhhb@shu.edu.cn

This work was supported by Program for Innovative Research Team in University (IRT 13078).

DOI: 10.1016/S1872-2067(15)60939-1 | http://www.sciencedirect.com/science/journal/18722067 | Chin. J. Catal., Vol. 36, No. 10, October 2015 
Sulfate generation using a combination of transition-metal ions with oxone or peroxymonosulfate (PMS) is a highly efficient method for the degradation of organic pollutants [3,7]; Co ions are the best activator [7]. However, the detrimental impact of Co dissolved in water on human health is a serious concern, therefore it is important to develop heterogeneous Co catalysts.

Environmental applications of various heterogeneous Co-based catalysts coupled with oxone or PMS have been investigated, i.e., unsupported $\mathrm{Co}$ oxides such as $\mathrm{Co}_{3} \mathrm{O}_{4}[5,8,9]$, unsupported Co-based mixed oxide composites such as Fe-Co mixed oxide nanocomposites [10-12], supported Co catalysts, including oxide-supported $\mathrm{Co}$ catalysts such as $\mathrm{TiO}_{2-}, \mathrm{Al}_{2} \mathrm{O}_{3-}$, $\mathrm{SiO}_{2-}, \mathrm{MgO}-, \mathrm{ZnO}-$, and $\mathrm{ZrO}_{2}$-loaded Co catalysts [13-18], carbon-supported Co catalysts such as Co/activated carbon [19], $\mathrm{Co} /$ carbon aerogel [20], $\mathrm{Co} /$ carbon xerogel [21], and $\mathrm{Co}_{3} \mathrm{O}_{4} /$ or $\mathrm{CoFe}_{2} \mathrm{O}_{4}$ /graphene oxide [22-24], Co-exchanged zeolites $[25,26]$, Co-exchanged resins [26], Co catalysts supported on industrial solid wastes such as Co/red mud and Co/fly ash [27], and mesoporous-material-supported Co catalysts such as Co/SBA-15 [28-30], Co/mesoporous $\mathrm{MnO}_{2}$ [31], and Co/MCM-41 [32]. Heterogeneous Co catalysts must have (1) high catalytic activity, reflected by the degradation efficiency and rate, and stability, represented by Co leaching in water and the recycling performance; and (2) convenient recovery of the catalyst after use for water and wastewater treatment [10]. The development of improved heterogeneous Co catalysts and the fabrication of novel heterogeneous co catalysts for pollution control are of great importance.

The porous material SBA-15 is a mesoporous silica molecular sieve with a highly ordered structure, large pore size, and high surface area [33,34]; these properties favor the loading and dispersion of catalytic active components and give good adsorption capabilities, thereby increasing the catalytic activity and stability. Previous investigations [28-30] showed that Co-supported SBA-15 coupled with PMS was effective in phenol and rhodamine $\mathrm{B}(\mathrm{RhB})$ degradation in water, and is stable. However, the use of Co-supported SBA-15 catalysts that are potentially excellent heterogeneous catalysts for oxone or PMS activation in the degradation of refractory organic pollutants need to be investigated further.

$\mathrm{RhB}$ is an important water-soluble xanthene organic dye. It is widely used in various industries, resulting in dye effluents. $\mathrm{RhB}$ in water is a threat to human health and the environment. The complex structure and stability of RhB make it resistant to biodegradation and photodegradation. The principal techniques available for removing $\mathrm{RhB}$ from water are adsorption [35], photocatalytic oxidation [36], the Fenton process [37], ultrasonic degradation [38], ozonation [39], and electrochemical oxidation [40]. Adsorption is convenient to operate and gives a high removal efficiency, but it only transfers the pollutants from the liquid phase to the solid phase, causing secondary pollution. Other techniques need special equipment or facilities, or have high energy consumption, leading to high capital and operating costs. The Fenton process is rapid and inexpensive, but it has several significant drawbacks such needing an acidic $\mathrm{pH}(\mathrm{pH} \mathrm{2-4)}$ and a high Fe dosage, which produces a large amount of Fe sludge, and the total organic carbon remov- al is less than $60 \%$.

In preliminary tests, we investigated the removal of $\mathrm{RhB}$ in aqueous solutions using Co/SBA-15-PMS or Fe/SBA-15-PMS systems. We found that Co/SBA-15 had high catalytic activity but could not be easily recovered because of its fine particle size. Degradation of RhB using Fe/SBA-15 was much slower than that with $\mathrm{Co} / \mathrm{SBA}-15$; the apparent reaction rate constant for Fe/SBA-15 was one-tenth that of CoFe/SBA-15. CoFe/SBA-15 was therefore expected to give better performance in the activation of PMS in RhB degradation, because it can maintain a high catalytic activity because of the presence of Co species, and provide different catalytic active sites and magnetism, enabling catalyst separation and recovery, because of the presence of Fe species. In this paper, SBA-15-supported Co and Fe was prepared and used to activate PMS to generate sulfate radicals for $\mathrm{RhB}$ degradation in aqueous solutions. The effects of the Co and Fe loadings and calcination temperature on the catalytic performance, and those of the CoFe/SBA-15 and PMS dosages and initial reactant concentrations on RhB degradation were investigated. A RhB degradation mechanism was proposed and the recycling performance of the CoFe/SBA-15 was investigated.

\section{Experimental}

\subsection{Preparation of SBA-15 and $\mathrm{CoFe} / \mathrm{SBA}-15$}

SBA-15 was prepared according to the procedure described by Zhao et al. [33]. Pluronic P123 triblock copolymer (EO20-PO70-EO20, Aldrich) and tetraethyl orthosilicate (TEOS, Aldrich) were used as the templating agent and silica source, respectively. In a typical synthesis, pluronic P123 (4.0 g) was dissolved in double-distilled water ( $30 \mathrm{~g}$ ) and $2 \mathrm{~mol} / \mathrm{L} \mathrm{HCl} \mathrm{(120}$ g, AR, Sinopharm Chemical Reagent Co., Ltd. (SCRC)) solution with stirring at $35^{\circ} \mathrm{C}$. TEOS (8.50 g) was added with stirring at $35^{\circ} \mathrm{C}$ for $20 \mathrm{~h}$. The mixture was aged at $80^{\circ} \mathrm{C}$ overnight without stirring. The solid product was recovered, washed, and air dried at room temperature. The dried solid was calcined in air at $500{ }^{\circ} \mathrm{C}$ for $6 \mathrm{~h}$. The heating rate was $1^{\circ} \mathrm{C} / \mathrm{min}$.

$\mathrm{CoFe} / \mathrm{SBA}-15$ catalysts were prepared via one-step incipient wetness impregnation using $\mathrm{Co}\left(\mathrm{NO}_{3}\right)_{2} \cdot 6 \mathrm{H}_{2} \mathrm{O}$ (AR, SCRC) and $\mathrm{Fe}\left(\mathrm{NO}_{3}\right)_{3} \cdot 9 \mathrm{H}_{2} \mathrm{O}$ (AR, SCRC) as the precursors, and SBA-15 as the support, with Co loadings of $3 \mathrm{wt} \%, 7 \mathrm{wt} \%, 10 \mathrm{wt} \%$, and 12 wt $\%$, and Fe loadings of 2.9 wt $\%, 4.8$ wt $\%, 6.7$ wt $\%, 9.5$ wt $\%$, $11.4 \mathrm{wt} \%$, and $19 \mathrm{wt} \%$. The appropriate amounts of $\mathrm{Co}\left(\mathrm{NO}_{3}\right)_{2} \cdot 6 \mathrm{H}_{2} \mathrm{O}$ and $\mathrm{Fe}\left(\mathrm{NO}_{3}\right)_{3} \cdot 9 \mathrm{H}_{2} \mathrm{O}$ were dissolved in distilled water under vigorous stirring. The suspension was stirred for $24 \mathrm{~h}$ and then mixed with SBA-15. The impregnated solids were dried at $60{ }^{\circ} \mathrm{C}$ for $10 \mathrm{~h}$, and then calcined in air at $400-700{ }^{\circ} \mathrm{C}$ for $5 \mathrm{~h}$. The heating rate was $10^{\circ} \mathrm{C} / \mathrm{min}$. The resulting catalysts were denoted by $m \mathrm{Co} n \mathrm{Fe} / \mathrm{SBA}-15-o$, where $m$, $n$, and $o$ represent a Co loading of $m$ wt $\%$, Fe loading of $n \mathrm{wt} \%$, and the calcination temperature $\left({ }^{\circ} \mathrm{C}\right)$, respectively.

\subsection{Characterization of prepared $\mathrm{CoFe} / \mathrm{SBA}-15$}

X-ray diffraction (XRD) patterns of the prepared samples 
were obtained using a Rigaku D/Max-2200X powder X-ray diffractometer with a $\mathrm{Cu} K_{\alpha}$ radiation $(\lambda=0.154056 \mathrm{~nm})$ at 40 $\mathrm{kV}$ and $40 \mathrm{~mA}$. Small-angle data were collected from $0.5^{\circ}$ to $5.0^{\circ}$ $(2 \theta)$ at a scanning speed of $0.5^{\circ} / \mathrm{min}$; wide-angle data were collected from $10^{\circ}$ to $80^{\circ}(2 \theta)$ at a scanning speed of $5^{\circ} / \mathrm{min} . \mathrm{N}_{2}$ adsorption-desorption isotherms were measured using a Micromeritics Tristar 3000 instrument at $-196{ }^{\circ} \mathrm{C}$. The specific surface areas were evaluated using the Brunauer-Emmett-Teller (BET) method in the $p / p_{0}$ range $0.02-0.20$. The pore size distributions were calculated using the Barrett-Joyner-Halenda method, based on the adsorption branch. The total pore volumes were determined from the data at $p / p_{0}$ $=0.99$. The surface morphologies of the samples were examined using scanning electron microscopy (JSM-6700F) with energy-dispersive X-ray spectroscopy (EDS). The internal structures of the samples were examined using high-resolution transmission electron microscopy (HR-TEM; JEM-2010F, JEOL, with a field-emission gun, $200 \mathrm{kV}$ ). The room-temperature magnetic properties of the samples were investigated using vibrating sample magnetometry (VSM; Lake Shore 7407) at magnetic fields up to $20 \mathrm{kOe}$.

\subsection{Catalytic oxidative degradation (catalytic reaction mode)}

RhB catalytic oxidative degradation tests were performed at $25{ }^{\circ} \mathrm{C}$ in $1000 \mathrm{~mL}$ glass reactors with $500 \mathrm{~mL}$ of magnetically stirred 5-25 mg/L RhB solution. The initial solution $\mathrm{pH}$ was not adjusted. CoFe/SBA-15 was added to the RhB solutions at dosages ranging from 0.05 to $0.2 \mathrm{~g} / \mathrm{L}$, and the suspensions were stirred for $5 \mathrm{~h}$ to achieve $\mathrm{RhB}$ adsorption-desorption equilibrium. The RhB concentrations at adsorption-desorption equilibrium were taken as the initial concentrations $\left(C_{0}\right)$ for the RhB catalytic oxidative degradation. A given amount of PMS $\left(\mathrm{KHSO}_{5}\right.$, the active component of oxone $\left(2 \mathrm{KHSO}_{5} \cdot \mathrm{KHSO}_{4} \cdot\right.$ $\mathrm{K}_{2} \mathrm{SO}_{4}$ ), Shanghai Future Chemical Technology Co., Ltd.) in the PMS/RhB molar ratio range 10:1-60:1 was added to the reactor to initiate the reaction. The reactor was covered to avoid volatilization. At fixed intervals, suspension samples $(7 \mathrm{~mL})$ were removed using a syringe and quenched with excess sodium nitrite to stop the reaction. The RhB concentrations in the aqueous solutions were determined using ultraviolet-visible (UV-vis) spectrophotometry (UV-5300PC) at $552 \mathrm{~nm}$. The Co concentrations in the solutions were measured by the nitroso-R-salt spectrophotometric method using a $722 \mathrm{E}$ visible spectrophotometer at $425 \mathrm{~nm}$. The Fe concentrations in the solutions were measured using inductively coupled plasma-atomic emission spectroscopy (Prodigy).

\subsection{RhB removal in presence of CoFe/SBA-15 and PMS (combined adsorption and catalytic reaction mode)}

In this investigation, the performances of CoFe/SBA-15 catalysts were investigated, in terms of the catalytic activity and stability, based on RhB removal, and Co and Fe leaching, respectively, in aqueous solutions. Co or Fe leaching was represented by the leaching concentration (dissolved Co or Fe concentration in solution) and leaching percentage (percentage loss of Co or Fe into the solution). For the combined adsorption and catalytic reaction tests, CoFe/SBA- 15 was added to the RhB solution, immediately followed by addition of PMS to initiate the reaction. The other steps were the same as those described above. All RhB removal tests were conducted using this operating mode, apart from the catalytic oxidative degradation tests. UV-vis spectra were obtained at different reaction times, in the scanning range 250-650 nm. For the CoFe/SBA-15 recycling tests, several parallel reactions were performed in every run up to the last one to ensure that sufficient material was available for the next run. The tests were conducted in duplicate and the experimental errors were below 3\%.

\section{Results and discussion}

\subsection{Characterization of SBA-15 and CoFe/SBA-15}

\subsection{1. $X R D$}

The small-angle XRD patterns of SBA-15 and 10C09.5Fe/SBA-15-700 are shown in Fig. 1. SBA-15 has an intense major diffraction peak corresponding to the (100) reflection and two additional peaks at higher degrees, corresponding to (110) and (200) reflections, respectively, indicating significant long-range order of the p6mm hexagonal symmetry. The diffraction peaks indexed to the (100), (110), and (200) reflections are also observed for 10Co9.5Fe/SBA-15-700, but the intensities are appreciably lower. This can be attributed to a decrease in the electron density contrast as a result of Co and Fe incorporation [41], implying that the supported Co and Fe species entered the SBA-15 channels.

Figure 2 shows the wide-angle XRD patterns of $m$ ConFe/SBA-15-o with various Co and Fe loadings and calcination temperatures. No distinct diffraction peaks were observed in the 3Co2.9Fe/SBA-15-700 (Fig. 2(a)); this implies that the Co and Fe species were highly dispersed on the SBA-15, preventing the formation of large crystallites. The reflection intensities increased significantly with increasing Co and Fe loadings, as a result of enhanced Co and Fe aggregation on the SBA-15 surface. However, calcination temperatures in the range 400-700 ${ }^{\circ} \mathrm{C}$ had little effect on the reflection intensities (Fig. 2(b)). The characteristic diffraction peaks of $\mathrm{CoFe}_{2} \mathrm{O}_{4}$ in Fig. 2 suggest that

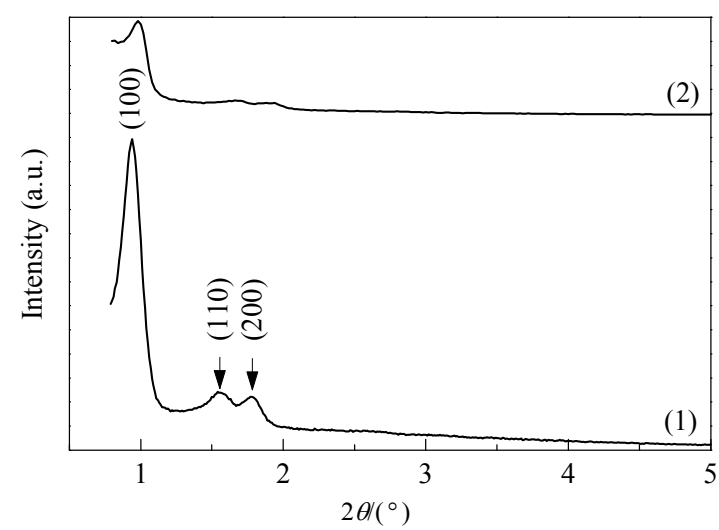

Fig. 1. Small-angle XRD patterns of SBA-15 (1) and 10Co9.5Fe/SBA15-700 (2). 

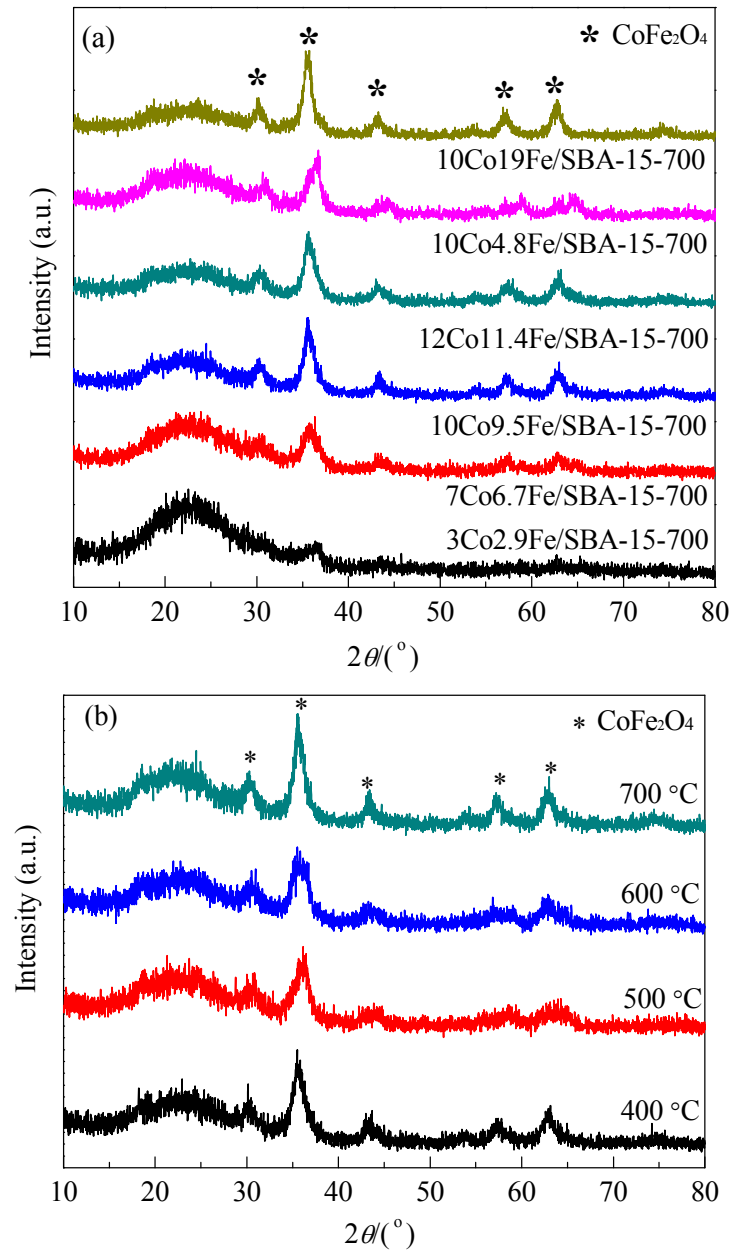

Fig. 2. Wide-angle XRD patterns of $m \mathrm{ConFe} / \mathrm{SBA}-15-700$ with different Co and Fe loadings (a) and 10Co9.5Fe/SBA-15 calcined at various temperatures (b).

Co and Fe were present mainly in the form of a $\mathrm{CoFe}_{2} \mathrm{O}_{4}$ composite in all the calcined samples. It has been reported that among the various linkages in $\mathrm{CoFe}_{2} \mathrm{O}_{4}$, i.e., $\mathrm{Co}-\mathrm{Co}, \mathrm{Fe}-\mathrm{Fe}$, and $\mathrm{Co}-\mathrm{Fe}$, the $\mathrm{Co}-\mathrm{Fe}$ interaction is the strongest [42]. The formation of abundant $\mathrm{CoFe}_{2} \mathrm{O}_{4}$ species can therefore suppress $\mathrm{Co}$ leaching.

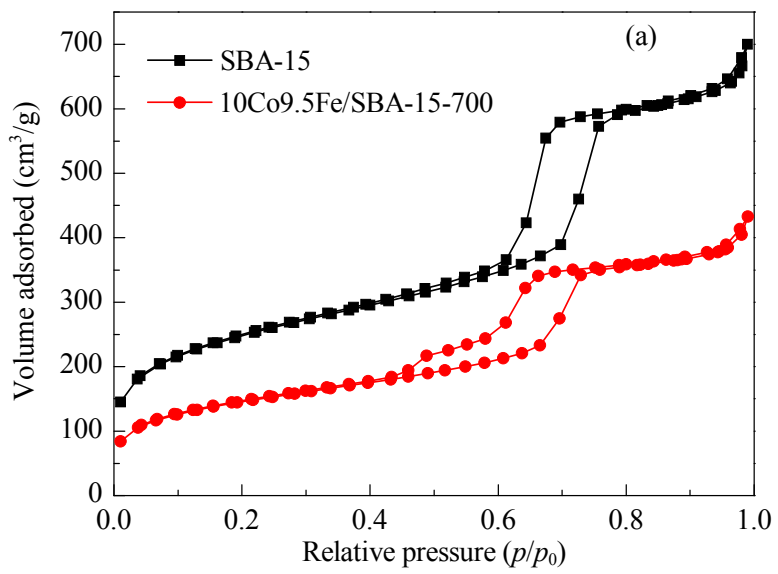

Table 1

Textural parameters of SBA-15 and 10Co9.5Fe/SBA-15-700.

\begin{tabular}{lccc}
\hline Sample & $\begin{array}{c}\text { BET surface } \\
\text { area }\left(\mathrm{m}^{2} / \mathrm{g}\right)\end{array}$ & $\begin{array}{c}\text { Pore volume } \\
\left(\mathrm{cm}^{3} / \mathrm{g}\right)\end{array}$ & $\begin{array}{c}\text { Pore diameter* } \\
(\mathrm{nm})\end{array}$ \\
\hline SBA-15 & 858.0 & 1.083 & 8.3 \\
10Co9.5Fe/SBA-15-700 & 506.1 & 0.669 & 7.4 \\
\hline
\end{tabular}

* calculated from the adsorption branch of the isotherm.

\subsection{2. $N_{2}$ adsorption-desorption}

The $\mathrm{N}_{2}$ adsorption-desorption isotherms of SBA-15 and 10Co9.5Fe/SBA-15-700 are shown in Fig. 3. Both samples had the type IV isotherm with an H1-type hysteresis loop resulting from capillary condensation of $\mathrm{N}_{2}$ in the mesopores; this is characteristic of mesoporous materials with cylindrical mesostructures. The isotherm of SBA-15 displayed a sharp jump at $p / p_{0}=0.6-0.8$, indicating that the sample had a typical mesostructure, with a uniform pore size distribution. However, the isotherm of $10 \mathrm{Co} 9.5 \mathrm{Fe} / \mathrm{SBA}-15-700$ showed a sharp jump at $p / p_{0}=0.4-0.8$, i.e., lower than that for SBA-15, indicating that the pore size of the SBA-15 support decreased after loading with Co and Fe species, and the supported species entered the SBA-15 channels.

The textural parameters of 10Co9.5Fe/SBA-15-700 are listed in Table 1. They show that the introduction of Co and $\mathrm{Fe}$ led to a $41 \%$ decrease in the specific surface area, $38 \%$ decrease in the pore volume, and $11 \%$ decrease in the pore diameter. This is because the Co-Fe composite formed by calcination occupied SBA-15 pore spaces. As shown in the inset in Fig. 3, SBA-15 and 10Co9.5Fe/SBA-15-700 both had a narrow pore size distribution, suggesting that the pore size distribution of SBA-15 was still uniform after Co and Fe species loading.

\subsubsection{SEM and EDS}

Figure 4 shows SEM images of SBA-15 and 10Co9.5Fe/ SBA-15-700. The images show that the samples consist of rod-like aggregates with diameters greater than $0.25 \mu \mathrm{m}$. A comparison of Figs. 4(b) and (d) shows a larger number of small particles attached to the surface of 10Co9.5Fe/SBA-15700, indicating that some Co-Fe composites agglomerated on the external surface of the catalyst, forming larger particles of diameter up to $100 \mathrm{~nm}$. The elements in 10Co9.5Fe/SBA-15-

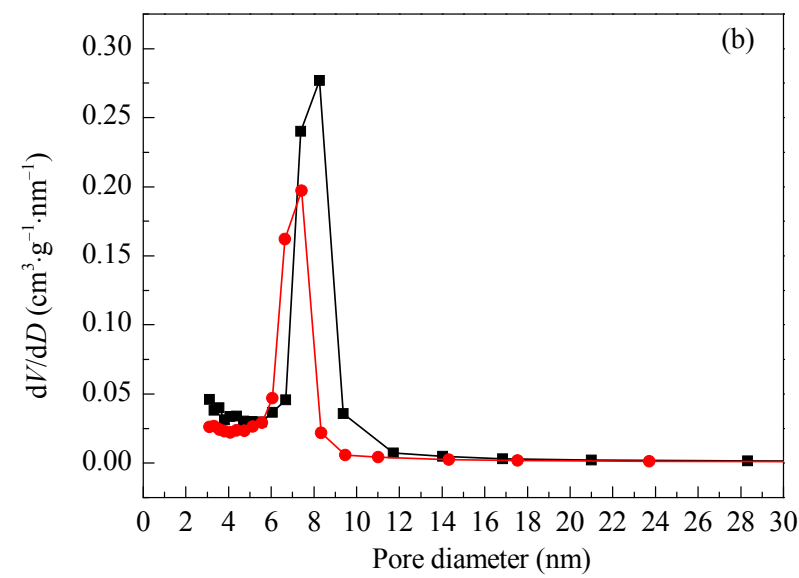

Fig. 3. $\mathrm{N}_{2}$ adsorption-desorption isotherms (a) and pore diameter distributions (b) for SBA-15 and 10Co9.5Fe/SBA-15-700. 

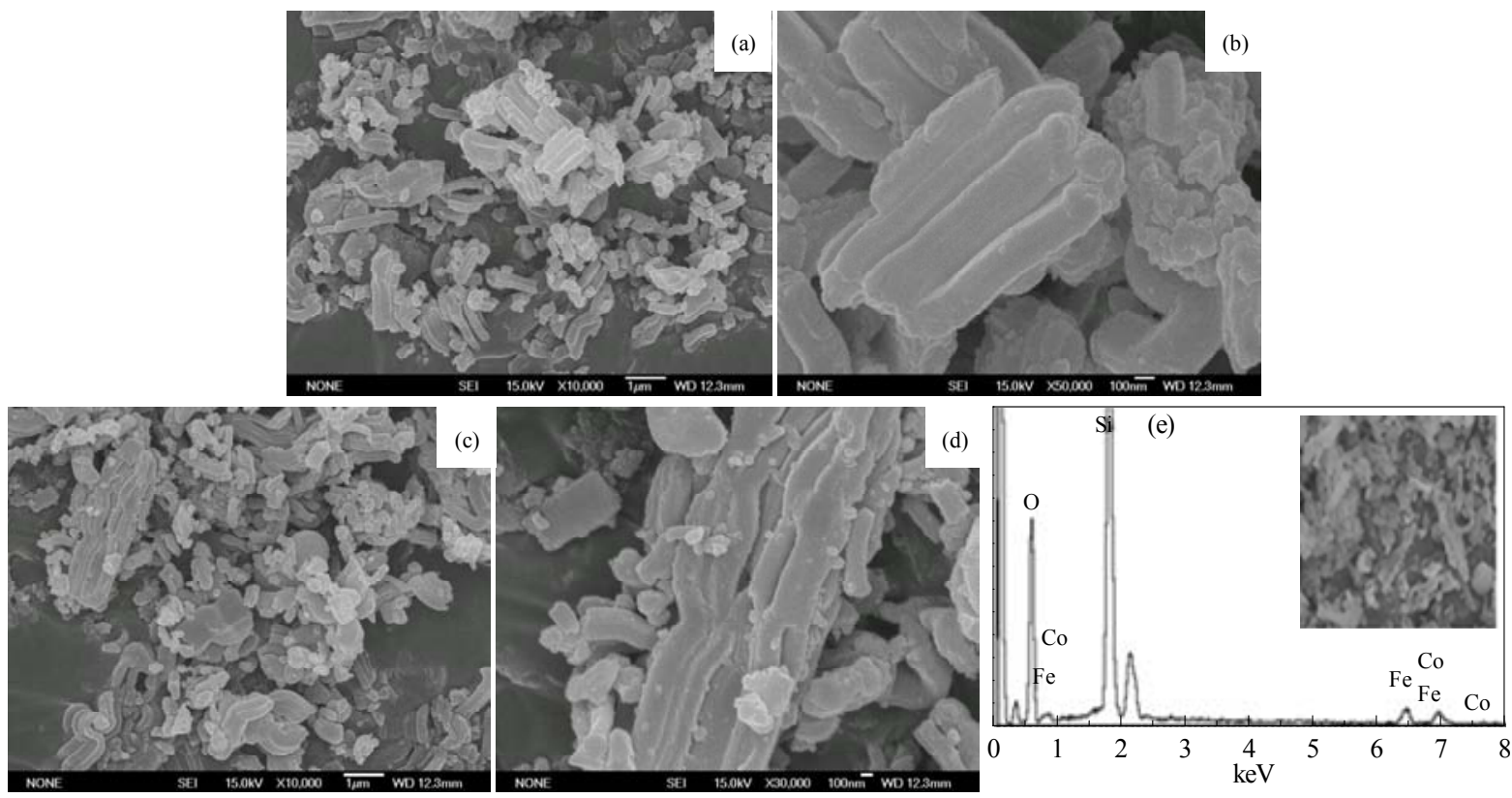

Fig. 4. SEM images of SBA-15 (a, b) and 10Co9.5Fe/SBA-15-700 (c, d), and EDS analysis of 10Co9.5Fe/SBA-15-700 (e).

700 were determined using EDS; the results are shown in Fig. 4(e). 10Co9.5Fe/SBA-15-700 contains Co, Fe, Si, and 0; Co and Fe account for $9.33 \mathrm{wt} \%$ and $8.93 \mathrm{wt} \%$, respectively, consistent with their theoretical values.

\subsubsection{TEM}

The TEM images of 10Co9.5Fe/SBA-15-700 in Fig. 5 show well-ordered hexagonal mesoporous channels. It can be seen from Fig. 5(a) that the formed $\mathrm{CoFe}_{2} \mathrm{O}_{4}$ nanoparticles were evenly dispersed in the SBA-15 channels, indicating that the nanoparticles had high crystallinity and phase purity, and that the supported catalyst retained the two-dimensional p6mm hexagonal mesostructure [33] after the introduction of $\mathrm{CoFe}_{2} \mathrm{O}_{4}$. The average thickness of the pore wall and the pore diameter were estimated to be around 4.95 and $6.6 \mathrm{~nm}$, respectively, based on the specific scale shown in Fig. 5(b); these values are consistent with those obtained from BET surface area analysis and the XRD results.

\subsubsection{VSM}

The magnetization curve for $10 \mathrm{Co} 9.5 \mathrm{Fe} / \mathrm{SBA}-15-700$ is
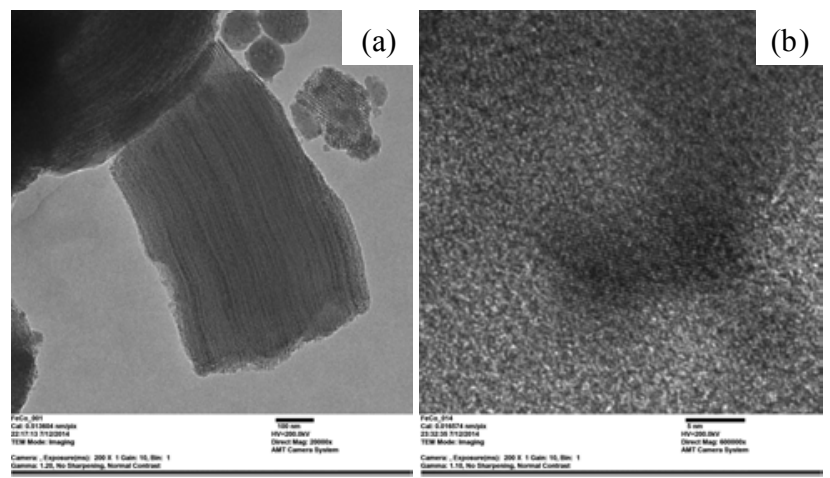

Fig. 5. TEM images (a) and HRTEM images (b) of $10 \mathrm{Co} .5 \mathrm{Fe} /$ SBA-15-700. shown in Fig. 6. The catalyst is magnetic, with a maximum magnetic intensity of $8.3 \mathrm{emu} / \mathrm{g}$; it can therefore be conveniently separated from water using a magnet. The convergence of the catalyst under the influence of an external magnet indicated the feasibility of catalyst reuse in practical applications. Among the Co-Fe oxides, i.e., $\mathrm{Co}_{3} \mathrm{O}_{4}, \mathrm{CoFe}_{2} \mathrm{O}_{4}$, and $\mathrm{Fe}_{2} \mathrm{O}_{3}$, that can be formed by calcination in the preparation of CoFe/SBA-15, only $\mathrm{CoFe}_{2} \mathrm{O}_{4}$ has magnetic properties, confirming that the mixed oxide $\mathrm{CoFe}_{2} \mathrm{O}_{4}$ was the major Co-Fe species on SBA-15 after calcination; this is consistent with the XRD results.

\subsection{Effects of CoFe/SBA-15 preparation conditions on catalytic performance}

\subsubsection{Calcination temperature}

Figure 7 shows the effect of calcination temperature on the catalytic performance, i.e., RhB removal and Co leaching in the presence of CoFe/SBA-15 and PMS. The results show that the effect of the calcination temperature on $\mathrm{RhB}$ removal is negligible, with RhB removal always being greater than 98\%; howev-

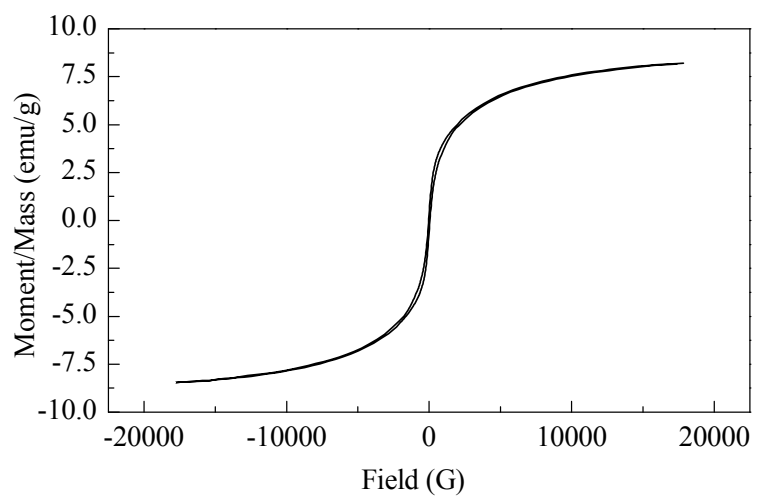

Fig. 6. Magnetization curve of 10Co9.5Fe/SBA-15-700. 

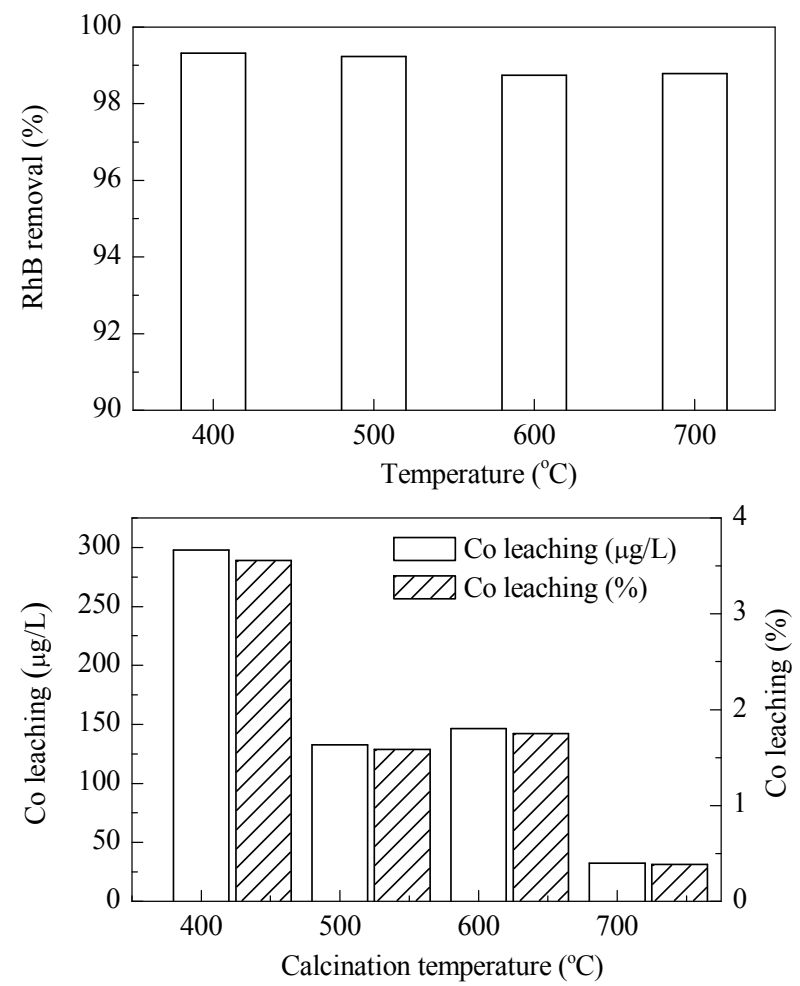

Fig. 7. Effects of calcination temperature on $\mathrm{RhB}$ removal and Co leaching. Reaction conditions: $C_{\mathrm{RhB}} 5.0 \mathrm{mg} / \mathrm{L}, 10 \mathrm{Co} 9.5 \mathrm{Fe} / \mathrm{SBA}-150.10$ $\mathrm{g} / \mathrm{L}, \mathrm{PMS} / \mathrm{RhB}$ molar ratio $20: 1,25^{\circ} \mathrm{C}, 2 \mathrm{~h}$, no solution $\mathrm{pH}$ adjustment.

er, the effect on Co leaching is significant. In general, a higher calcination temperature suppressed Co leaching. The maximum Co leaching concentration, i.e., $297.8 \mu \mathrm{g} / \mathrm{L}(3.5 \%)$, and the minimum Co leaching concentration, $32.4 \mu \mathrm{g} / \mathrm{L}(0.4 \%)$, were achieved at 400 and $700{ }^{\circ} \mathrm{C}$, respectively, indicating that the calcination temperature significantly affected the CoFe/SBA-15 stability. It can be inferred that $\mathrm{Co}$ and Fe species were attached to the support more firmly after calcination at $700{ }^{\circ} \mathrm{C}$.

\subsubsection{Co and Fe loadings}

Figure 8 shows the effects of $\mathrm{Co}$ and Fe loadings on RhB removal and Co leaching for CoFe/SBA-15-700. As the results shown, the effects of the Co and Fe loadings on RhB removal were insignificant; the RhB removal exceeded $96 \%$. The effects on Co leaching were also negligible, with Co leaching ranging from 20 to $60 \mu \mathrm{g} / \mathrm{L}$. At $3 \mathrm{wt} \%$ Co loading, the Co leaching concentration and percentage were $23.3 \mu \mathrm{g} / \mathrm{L}$ and $0.82 \%$, respectively, and at $10 \mathrm{wt} \%$ Co loading, the Co leaching concentration and percentage were $32.4 \mu \mathrm{g} / \mathrm{L}$ and $0.39 \%$, respectively. Although the Co leaching concentrations are similar in the above cases, the Co leaching percentage in the latter case is only half that in the former. 10Co9.5Fe/SBA-15-700 displayed the highest catalytic activity and negligible Co leaching, and is therefore considered to be the best catalyst.

\subsection{Preliminary tests}

As a preliminary test, the changes in RhB concentration in aqueous solution with time under different operating modes

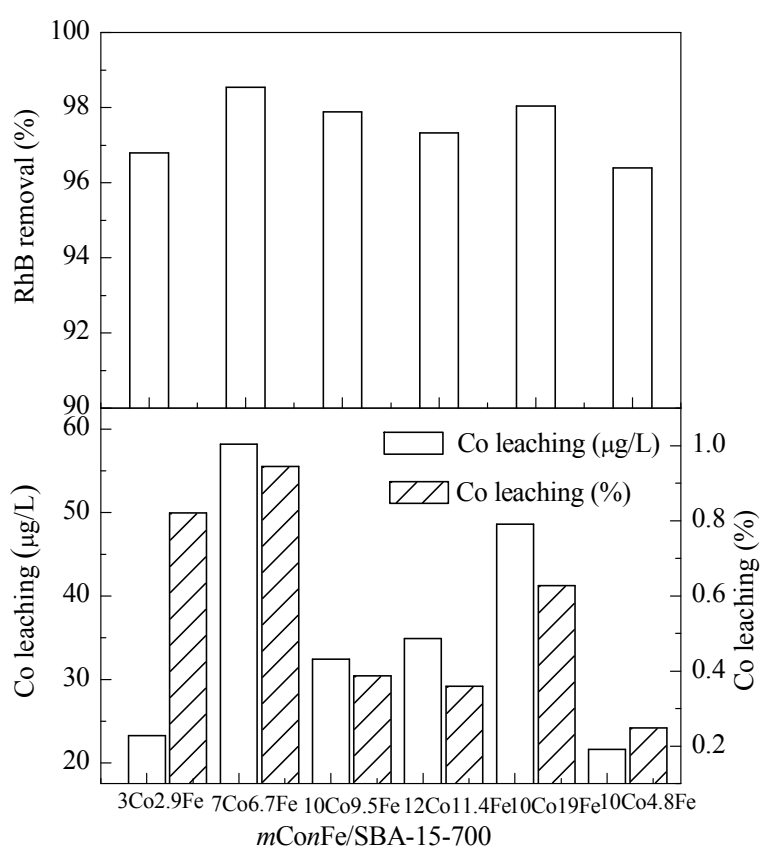

Fig. 8. Effects of Co and Fe loadings on RhB removal and Co leaching. Reaction conditions: $C_{\mathrm{RhB}} 5.0 \mathrm{mg} / \mathrm{L}, \quad \mathrm{CoFe} / \mathrm{SBA}-15-700 \quad 0.10 \mathrm{~g} / \mathrm{L}$, PMS/RhB molar ratio $20: 1,25^{\circ} \mathrm{C}, 2 \mathrm{~h}$, no solution $\mathrm{pH}$ adjustment.

were investigated: simple adsorption by $10 \mathrm{Co} 9.5 \mathrm{Fe} /$ SBA-15-700, chemical oxidation with PMS alone, and a combination; the results are shown in Fig. 9. The results show that the contribution of chemical oxidation by PMS to RhB removal is negligible. Simple adsorption by $10 \mathrm{Co} 9.5 \mathrm{Fe} / \mathrm{SBA}-15-700$ can remove approximately $45 \%$ of $\mathrm{RhB}$ in solution, and approximately $98 \% \mathrm{RhB}$ removal can be achieved in $2 \mathrm{~h}$ in the presence of $10 \mathrm{Co} 9.5 \mathrm{Fe} / \mathrm{SBA}-15-700$ and PMS, suggesting that an important chemical reaction occurs in the system consisting of CoFe/SBA-15, PMS, and RhB in solution, i.e., the activation of PMS by $10 \mathrm{Co}$.5Fe/SBA-15-700 and subsequent generation of sulfate radicals, leading to $\mathrm{RhB}$ degradation in aqueous solutions.

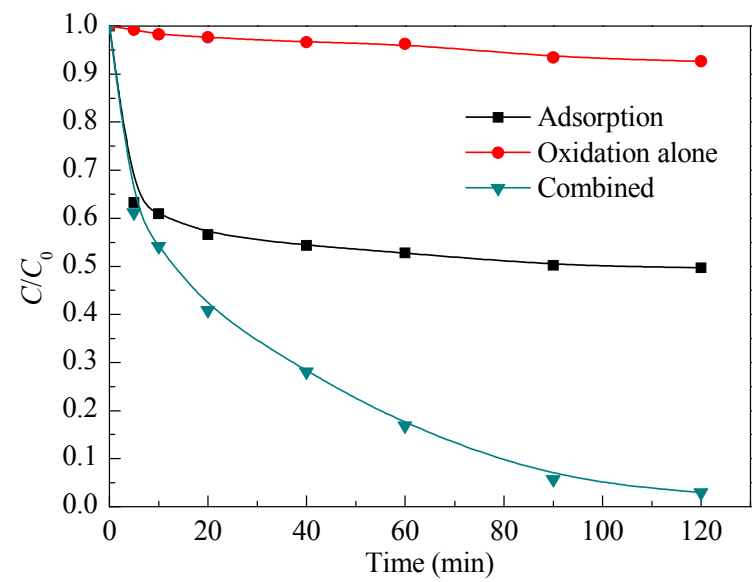

Fig. 9. Removal of $\mathrm{RhB}$ in aqueous solution under three operational modes. Reaction conditions: $C_{\mathrm{RhB}} 5.0 \mathrm{mg} / \mathrm{L}, \mathrm{CoFe} / \mathrm{SBA}-15-7000.10 \mathrm{~g} / \mathrm{L}$, PMS/RhB molar ratio $20: 1,25^{\circ} \mathrm{C}, 2 \mathrm{~h}$, no solution $\mathrm{pH}$ adjustment. 


\subsection{Kinetics of catalytic oxidative degradation of $R h B$ in the presence of CoFe/SBA-15 and PMS}

Evaluation of the catalytic activity of CoFe/SBA-15 should be based on the catalytic oxidative degradation of RhB rather than on RhB adsorption on CoFe/SBA-15. It is necessary to investigate the $\mathrm{RhB}$ degradation kinetics to understand $\mathrm{RhB}$ degradation in the presence of CoFe/SBA-15 and PMS. Accordingly, three groups of tests, described below, were conducted in catalytic reduction mode, using $10 \mathrm{Co} 9.5 \mathrm{Fe} / \mathrm{SBA}-15-700$ as a representative CoFe/SBA-15 catalyst.

\subsubsection{Effect of 10Co9.5Fe/SBA-15-700 dosage}

$10 \mathrm{Co} 9.5 \mathrm{Fe} / \mathrm{SBA}-15-700$ was used as the catalyst to activate the PMS oxidant to produce active sulfate radicals, with RhB as the target compound for radical attack, in the heterogeneous system 10Co9.5Fe/SBA-15-700-PMS-RhB in catalytic reaction mode. The generation of sulfate radicals is important in RhB degradation and is significantly affected by the catalyst and oxidant. The effect of the 10Co9.5Fe/SBA-15-700 dosage on the degradation kinetics was investigated first; the RhB degradation rate constant $k_{1}$ and Co leaching rates at different 10Co9.5Fe/SBA-15-700 dosages in the presence of PMS are shown in Fig. 10. The inset in Fig. 10(a) shows the kinetic curves of RhB degradation; these illustrate that RhB degradation corresponds well to the first-order kinetic model $\ln C / C_{0}=$ $-k_{1} t$, where $C$ and $C_{0}$ are the RhB concentrations at time $t$ and $t$ $=0$, respectively. Figure 10 (a) shows that the rate constant $k_{1}$ jumps, increasing from approximately 0.017 to $0.032 \mathrm{~min}^{-1}$, as the catalyst loading increases from 0.05 to $0.10 \mathrm{~g} / \mathrm{L}$. At catalyst loadings above $0.10 \mathrm{~g} / \mathrm{L}, k_{1}$ is constant, at approximately 0.032 $\min ^{-1}$. A higher catalyst dosage increases the number of adsorption sites and provides more active sites for activating sulfate radical generation by PMS, and therefore leads to a significant enhancement in the oxidative degradation rate. In addition, it has been reported that for degradation in the presence of PMS alone at a PMS/RhB molar ratio of 20:1, a decrease in the RhB concentration of less than $15 \%$ occurred in $120 \mathrm{~min}$, confirming the critical role of the CoFe/SBA-15 catalyst in RhB degradation [30].

Co leaching rates at representative catalyst dosages in the presence of PMS and RhB are shown in Fig. 10(b); Co leaching was negligible in ordinary $\mathrm{RhB}$ aqueous solution. As shown in Fig. 10(b), Co leaching increased significantly from less than $32.4 \mu \mathrm{g} / \mathrm{L} \quad(0.39 \%)$ to $120.9 \mu \mathrm{g} / \mathrm{L} \quad(0.72 \%)$ as the 10Co9.5Fe/SBA-15-700 dosage increased from 0.1 to $0.2 \mathrm{~g} / \mathrm{L}$; at a $10 \mathrm{Co} 9.5 \mathrm{Fe} / \mathrm{SBA}-15-700$ loading greater than $0.10 \mathrm{~g} / \mathrm{L}$, the degradation rate constant $k_{1}$ was maximum and approximately constant, i.e., $0.032 \mathrm{~min}^{-1}$, indicating the fastest RhB degradation rate, fastest generation rate of organic acid intermediates, and the most acidic solution, which is favorable for Co leaching. Moreover, loading of a larger number of Co species in the acidic solution would lead to more Co leaching in the solution. Melero et al. [43] investigated the catalytic wet peroxidation of phenolic aqueous solutions with $\mathrm{Fe}_{2} \mathrm{O}_{3}$ /SBA-15, and found that a significant decrease in the solution $\mathrm{pH}$ resulted in higher $\mathrm{Fe}$ leaching; this was associated with the formation of organic carboxylic acids as the main byproducts of the partial oxidation of phenolic compounds. These observations are similar to ours. It was also reported that $\mathrm{RhB}$ degradation increased from $39 \%$ to $72 \%$ in $60 \mathrm{~min}$ in a homogeneous Co(II)-PMS system as the Co ion concentration increased from 50 to $200 \mu \mathrm{g} / \mathrm{L}$, while keeping the $\mathrm{RhB}$ concentration and $\mathrm{PMS} / \mathrm{RhB}$ molar ratio at 5.0 $\mathrm{mg} / \mathrm{L}$ and 20:1, respectively [30]. In comparison, RhB degradation was much higher in our heterogeneous system, with Co leaching into solution, showing a heterogeneous reaction mechanism rather than a homogeneous one.

\subsubsection{Effect of PMS dosage}

Figure 11 shows the catalytic oxidative degradation rate constant $k_{1}$ and Co leaching rates at different PMS dosages in the presence of $10 \mathrm{Co} 9.5 \mathrm{Fe} / \mathrm{SBA}-15-700$. The inset in Fig. 11(a) shows the kinetic curves for RhB degradation; they illustrate that RhB degradation followed the first-order kinetic model well. The initial RhB concentration of the solution was as low as $5.0 \mathrm{mg} / \mathrm{L}$, to simulate dilute effluent, therefore the RhB degradation rate was related to the instantaneous concentration of $\mathrm{RhB}$, and was one of the rate-limiting factors. Figure 11(a) shows that the kinetic rate constant increased with increasing PMS dosage, with $k_{1}$ equaling $0.042 \mathrm{~min}^{-1}$ at a PMS/RhB molar ratio of $60: 1$. Because PMS is the origin of the reactive sulfate radicals, increasing the PMS dosage promotes generation of
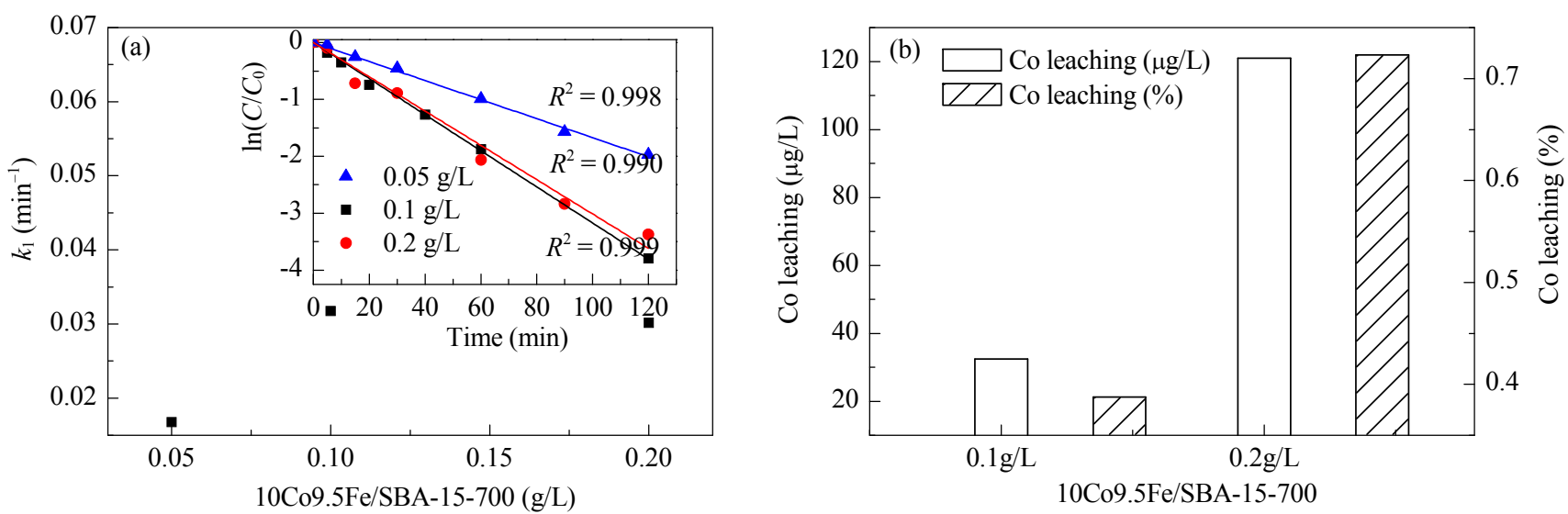

Fig. 10. Performances of catalyst at various $10 \mathrm{Co} 9.5 \mathrm{Fe} / \mathrm{SBA}-15-700$ dosages in the presence of PMS and RhB. (a) RhB degradation kinetics; (b) Co leaching. Reaction conditions: $C_{\mathrm{RhB}} 5.0 \mathrm{mg} / \mathrm{L}$, PMS/RhB molar ratio $20: 1,25^{\circ} \mathrm{C}, 2 \mathrm{~h}$, no solution $\mathrm{pH}$ adjustment. 

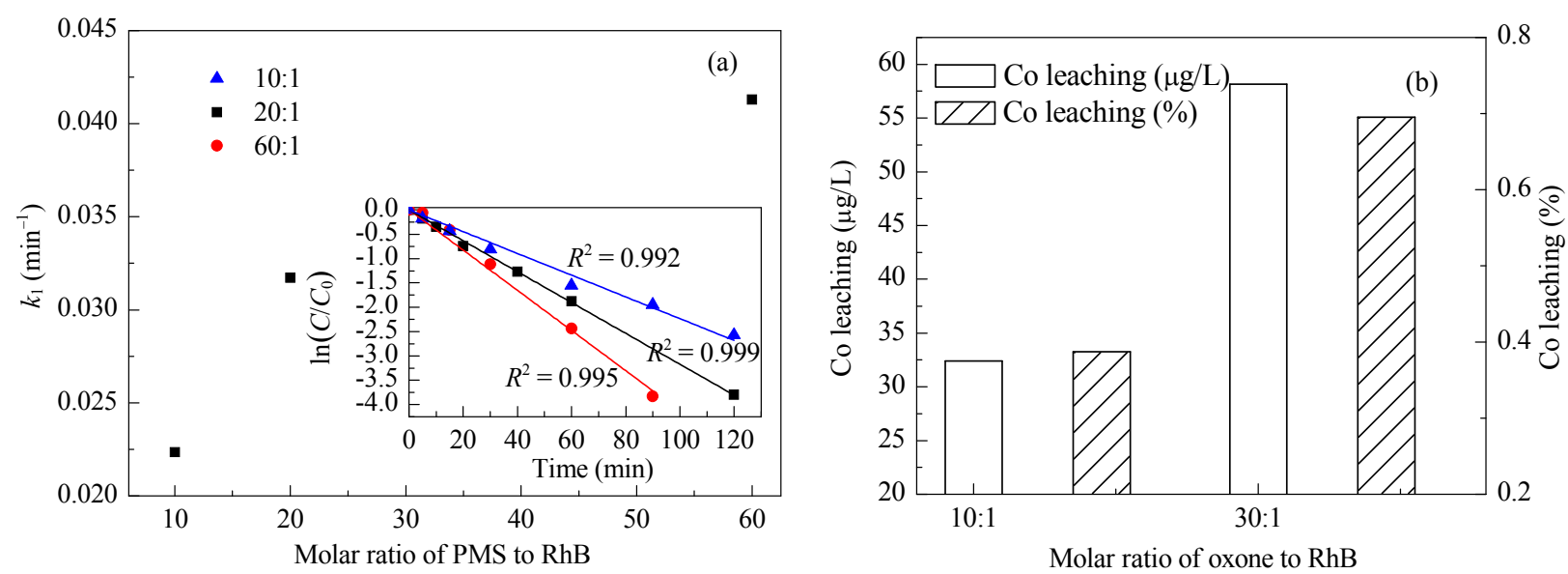

Fig. 11. Performances of $10 \mathrm{Co} 9.5 \mathrm{Fe} / \mathrm{SBA}-15-700$ catalyst at various PMS dosages in the presence of RhB. (a) RhB degradation kinetics; (b) Co leaching. Reaction conditions: $C_{\mathrm{RhB}} 5.0 \mathrm{mg} / \mathrm{L}, 10 \mathrm{Co} 9.5 \mathrm{Fe} / \mathrm{SBA}-15-7000.10 \mathrm{~g} / \mathrm{L}, 25^{\circ} \mathrm{C}, 2 \mathrm{~h}$, no solution $\mathrm{pH}$ adjustment.

sulfate radicals, resulting in a faster degradation rate. It has been reported that further increasing the PMS dosage leads to lower degradation rates for organic materials in systems consisting of a Co-based catalyst and PMS because of self-quenching of sulfate radicals by PMS, as shown in equation (3) [44].

$$
\mathrm{HSO}_{5}{ }^{-}+\mathrm{SO}_{4}{ }^{--} \rightarrow \mathrm{SO}_{5}{ }^{--}+\mathrm{SO}_{4}{ }^{2-}+\mathrm{H}^{+}
$$

However, significant self-quenching resulting from a higher PMS dosage was not observed in this investigation, probably because the proportions of the CoFe/SBA-15 catalyst, PMS oxidant, and RhB target compound were appropriate.

As observed in Fig. 11(b), the Co leaching concentration and percentage increased from $32.4 \mu \mathrm{g} / \mathrm{L}$ and $0.39 \%$ to $58.2 \mu \mathrm{g} / \mathrm{L}$ and $0.70 \%$, respectively. The increased Co leaching can be ascribed to the increased acidity of the solution as a result of the increased acidic oxidant (oxone) dosage and generation of acidic intermediates during degradation.

\subsubsection{Effect of different initial reactant concentrations}

Figure 12 shows the kinetic rate constants $k_{1}$ and Co leaching rates at different initial reactant (RhB and PMS) concentrations with a fixed PMS/RhB molar ratio of 20:1 in the presence of $10 \mathrm{Co} .5 \mathrm{Fe} / \mathrm{SBA}-15-700$. The inset in Fig. 12(a) shows the kinetic curves for RhB degradation, and these indicate that RhB degradation still obeyed the first-order kinetic model with respect to the substrate, i.e., RhB. Figure 12(a) shows that the kinetic rate constant declined from 0.032 to $0.010 \mathrm{~min}^{-1}$ with increasing initial RhB concentration from 5 to $25 \mathrm{mg} / \mathrm{L}$ coupled with an increase in the initial PMS concentration from 32 to $159 \mathrm{mg} / \mathrm{L}$. The increases in the initial RhB and PMS concentrations result in the production of larger amounts of intermediates and carbonaceous deposits on the catalyst during RhB degradation, leading to active site blockage. This is why the degradation rate decreased with increasing initial reactant concentrations. Ramirez et al. [45] investigated azo-orange II degradation via a heterogeneous Fenton-like reaction, using Fe/carbon catalysts. They attributed the observed Fe/active carbon catalyst deactivation to Fe complexation with oxalic acid and/or to active site blockage by polymeric deposits. This explanation is similar to ours. It was observed that the initial $\mathrm{pH}$ of the suspension of CoFe/SBA-15, PMS, and RhB decreased from 5.2 to 3.8 when the initial $\mathrm{RhB}$ concentration increased from 5 to $25 \mathrm{mg} / \mathrm{L}$ while keeping the PMS/RhB molar ratio at 20:1, because PMS and RhB are both acidic compounds. At low $\mathrm{pH}$ values, the formation of $\mathrm{Co}-\mathrm{OH}$ complexes on the Co cata-
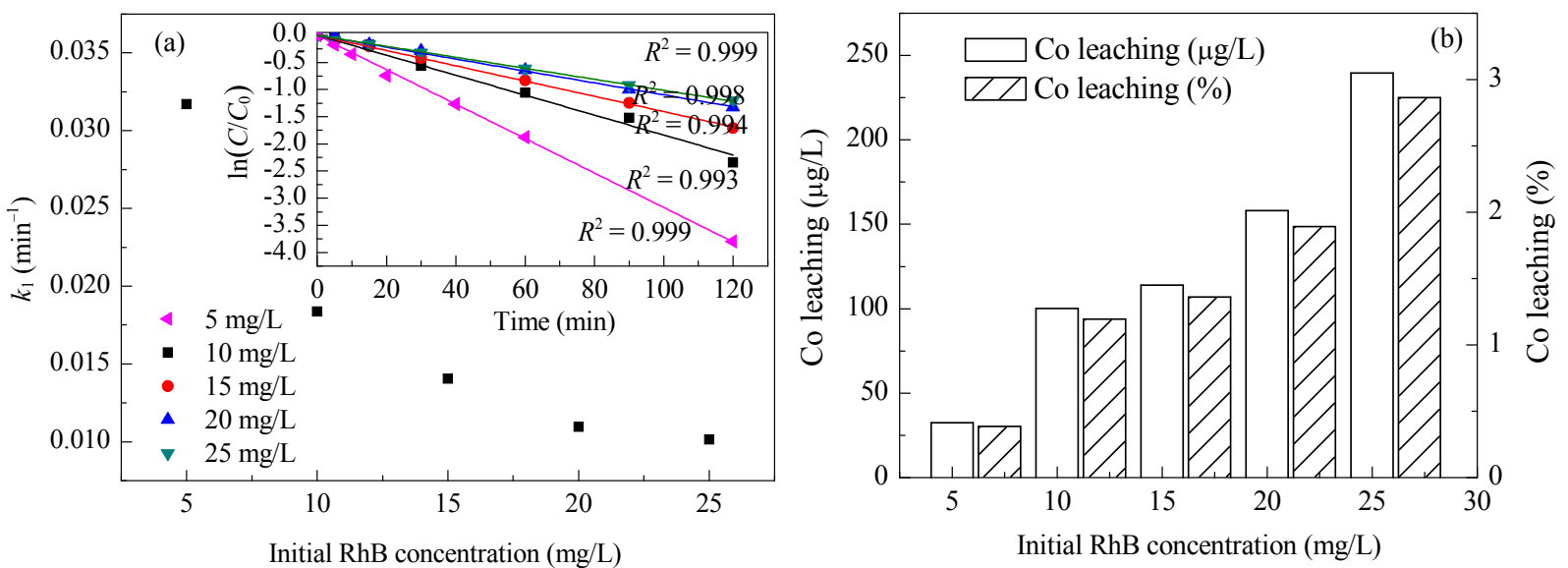

Fig. 12. Performances of $10 \mathrm{Co} 9.5 \mathrm{Fe} / \mathrm{SBA}-15-700$ catalyst at various reactants (PMS and RhB) concentrations. (a) RhB degradation kinetics; (b) Co leaching. Reaction conditions: PMS/RhB molar ratio 20:1, 10Co9.5Fe/SBA-15-700 0.10 g/L, $25^{\circ} \mathrm{C}, 2 \mathrm{~h}$, no solution pH adjustment. 
lyst surface decreased, which inhibited heterogeneous activation of PMS and decreased the RhB degradation rate [18]. Su et al. [12] investigated the influence of $\mathrm{pH}$ on $\mathrm{RhB}$ degradation in $\mathrm{Co}_{x} \mathrm{Fe}_{3-x} \mathrm{O}_{4}$ /oxone systems, and found that the degradation rate was low under strongly acidic and alkaline conditions. Anipsitakis et al. [46] reported similar results. These results are similar to ours. The decrease in the solution $\mathrm{pH}$ as a result of increasing the initial reactant concentrations is therefore also responsible for the reduced $\mathrm{RhB}$ degradation rate in the CoFe/SBA-15-PMS system.

Figure 12(b) shows that Co leaching increased with increasing initial reactant concentrations. As explained above, higher concentrations of the reactants (PMS and RhB) increase the suspension acidity, which promotes dissolution of supported metallic species such as Co ions in aqueous solution.

Table 2 lists most of the reported rate constants for the first-order kinetics of organic degradation in the presence of PMS and Co-loaded catalysts with different supports. As shown in Table 2, in various cases, CoFe/SBA-15 coupled with PMS for degradation of the non-biodegradable organic dye RhB gave high degradation rate constants. It is also worth noting that the catalytic activity of CoFe/SBA-15 is lower than that of Co/SBA-15 under similar reaction conditions: $\mathrm{RhB}$ concentration $5.0 \mathrm{mg} / \mathrm{L}$, Co/SBA-15 or 10Co9.5Fe/SBA-15-700 dosage $0.10 \mathrm{~g} / \mathrm{L}, \mathrm{PMS} / \mathrm{RhB}$ molar ratio $60: 1,25^{\circ} \mathrm{C}, 2 \mathrm{~h}$, and no solution $\mathrm{pH}$ adjustment. This phenomenon can be attributed to the different catalysts having different degradation mechanisms.

\subsection{Mechanism of RhB removal from aqueous solutions in presence of $\mathrm{CoFe} / \mathrm{SBA}-15$ and $P M S$}

\subsubsection{UV-vis spectroscopy}

The pathway of RhB degradation was explored by examining the UV-vis spectra of RhB degradation in the presence of a catalyst and oxidant. Figure 13 shows the temporal evolution of spectral changes during RhB degradation in the presence of 10Co9.5Fe/SBA-15-700 and PMS. It is generally accepted that RhB degradation occurs via two competitive processes: continuous $\mathrm{N}$-de-ethylation, and destruction of anthracene rings $[47,48]$. It shows that there is no significant blue shift of the maximum adsorption peak at $552 \mathrm{~nm}$ and only a gradual decrease in the intensity, and no new bands are formed. These results indicate that the major RhB degradation pathway is the destruction of anthracene rings, and there is no complex formation among CoFe/SBA-15, PMS, and RhB. It can therefore be

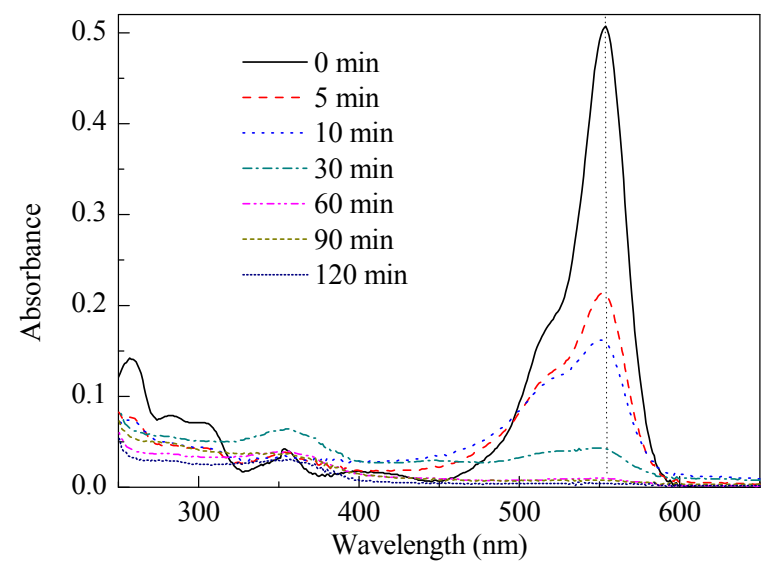

Fig. 13. UV-vis spectra of RhB degradation on 10Co9.5Fe/SBA-15-700. Reaction conditions: $C_{\mathrm{RhB}} 5.0 \mathrm{mg} / \mathrm{L}, 10 \mathrm{Co} 9.5 \mathrm{Fe} / \mathrm{SBA}-15-700$ dosage 0.10 $\mathrm{g} / \mathrm{L}, \mathrm{PMS} / \mathrm{RhB}$ molar ratio $20: 1,25^{\circ} \mathrm{C}, 2 \mathrm{~h}$, no solution $\mathrm{pH}$ adjustment.

concluded that the $\mathrm{SO}_{4}{ }^{--}$radicals generated by PMS activation by $10 \mathrm{Co}$.5Fe/SBA-15-700 preferentially attack the aromatic hydrocarbon rings, and decompose $\mathrm{RhB}$ molecules to small-molecule organics in $60 \mathrm{~min}$. The reduction in the intensity of the absorbance peak in the initial degradation phase does not exclude RhB adsorption on the 10Co9.5Fe/ SBA-15-700 catalyst.

Yang et al. [10] developed an efficient and environmentally benign Fe-Co mixed oxide nanocatalyst for heterogeneous activation of PMS to generate sulfate radicals for the decomposition of 2,4-dichlorophenol, and found that a $\mathrm{CoFe}_{2} \mathrm{O}_{4}$ catalyst had the following physicochemical properties. (1) The Co species in $\mathrm{CoFe}_{2} \mathrm{O}_{4}$ are present as $\mathrm{Co}(\mathrm{II})$, which avoids the detrimental effect of $\mathrm{Co}(\mathrm{III})$ on PMS activation. (2) $\mathrm{CoFe}_{2} \mathrm{O}_{4}$ suppresses Co leaching because of strong Fe-Co interactions, i.e., Fe-Co linkages. (3) $\mathrm{CoFe}_{2} \mathrm{O}_{4}$ is easy to recovery because of its ferromagnetic nature. (4) The conjunction of Co with Fe increases the number of hydroxyl groups on the catalyst surface, and this facilitates the formation of $\mathrm{Co}(\mathrm{II})-\mathrm{OH}$ complexes, which are vital to heterogeneous PMS activation. In this investigation, the predominant Co-Fe oxide loaded on the SBA-15 support was the mixed oxide composite $\mathrm{CoFe}_{2} \mathrm{O}_{4}$, which provided the active catalytic sites of $\mathrm{CoFe} / \mathrm{SBA}-15$. This catalyst has a moderate RhB adsorption capacity in aqueous solutions, and high catalytic activity and stability, reflected by the achieved RhB degradation of more than $98 \%$ and Co leaching of

Table 2

Rate constants for first-order kinetics of organic compound degradation in the presence of Co-loaded catalysts and PMS.

\begin{tabular}{|c|c|c|c|c|}
\hline Catalyst & Model compound & Rate constant $k_{1}\left(\mathrm{~min}^{-1}\right)$ & $R^{2}$ & Ref. \\
\hline Co/activated carbon & Phenol & 0.125 & 0.991 & [19] \\
\hline Co/carbon-aerogel & Phenol & 0.0289 & 0.992 & [20] \\
\hline Co/carbon-xerogel & Phenol & 0.0916 & 0.982 & [21] \\
\hline $\mathrm{CoFe}_{2} \mathrm{O}_{4}$ /grapheme oxide & Phenol & 0.1001 & 0.982 & [22] \\
\hline Co/red mud & Phenol & 0.0371 & - & [27] \\
\hline Co/fly ash & Phenol & 0.00513 & - & [27] \\
\hline $\mathrm{Co} /$ mesoporous $\mathrm{MnO}_{2}$ & Phenol & 0.0425 & 0.996 & [29] \\
\hline Co/resin & Monuron (herbicide ) & 0.110 & 0.950 & [26] \\
\hline Co/SBA-15 & $\mathrm{RhB}$ & 0.063 & 0.971 & [30] \\
\hline CoFe/SBA-15 & $\mathrm{RhB}$ & 0.042 & 0.995 & This work \\
\hline
\end{tabular}


Table 3

Quenching tests with different molar ratio of quenching agent/PMS.

\begin{tabular}{lcc}
\hline Molar ratio of & \multicolumn{2}{c}{ RhB removal (\%) } \\
\cline { 2 - 3 } quenching agent/PMS & EtOH & TBA \\
\hline $0: 1$ & 97.1 & 97.1 \\
$4000: 1$ & 83.1 & 97.0 \\
$6000: 1$ & 73.8 & 97.2 \\
$8000: 1$ & 63.1 & 96.7 \\
\hline
\end{tabular}

less than $32.4 \mu \mathrm{g} / \mathrm{L}$. These results suggest that the mechanism of $\mathrm{RhB}$ removal from aqueous solutions in the presence of CoFe/SBA-15 and PMS is as follows.

$$
\begin{aligned}
& \mathrm{HSO}_{5}{ }^{-} \text {bulk } \rightarrow \mathrm{HSO}_{5}{ }^{-} \mathrm{BL} \rightarrow \mathrm{HSO}_{5}{ }^{-} \text {interface } \\
& \mathrm{RhB}_{\text {bulk }} \rightarrow \mathrm{RhB}_{\mathrm{BL}} \rightarrow \mathrm{RhB} \text { interface } \\
& \text { MS-Fe }{ }^{3+}+\mathrm{H}_{2} \mathrm{O}_{\text {interface }} \rightarrow \mathrm{MS}-\mathrm{FeOH}^{2+}+\mathrm{H}^{+} \text {bulk } \\
& \text { (MS: mesoporous silica) }
\end{aligned}
$$

$\mathrm{MS}-\mathrm{Co}^{2+}+\mathrm{MS}-\mathrm{FeOH}^{2+} \rightarrow \mathrm{MS}-\mathrm{CoOH}^{+}+\mathrm{MS}^{-} \mathrm{Fe}^{3+}$ (slow) (7) $\mathrm{MS}-\mathrm{CoOH}^{+}+\mathrm{HSO}_{5}{ }^{-}$interface $\rightarrow \mathrm{MS}-\mathrm{CoO}^{+}+\mathrm{SO}_{4}{ }^{-{ }^{-}}$interface $+\mathrm{H}_{2} \mathrm{O}_{\text {bulk }}$

$\mathrm{RhB}\left(\mathrm{C}_{28} \mathrm{H}_{31} \mathrm{ClN}_{2} \mathrm{O}_{3}\right)_{\text {interface }}+\mathrm{SO}_{4}{ }^{\cdot-}$ interface $\rightarrow \mathrm{RhB}^{-} \mathrm{SO}_{4}{ }^{\cdot-}$ (fast)(9) $\mathrm{RhB}-\mathrm{SO}_{4}{ }^{-}{ }^{-}$several steps $\rightarrow \mathrm{CO}_{2 \text { bulk }}+\mathrm{H}_{2} \mathrm{O}_{\text {bulk }}+\mathrm{NO}_{3 \text { bulk }}{ }^{-}+\mathrm{NH}_{4}{ }^{+}$buk

where the subscripts bulk, BL, and interface indicate species in bulk solution, at the boundary layer, and on the solid-liquid interface, respectively; $\mathrm{MS}-\mathrm{Fe}^{3+}$ and $\mathrm{MS}-\mathrm{Co}^{2+}$ are the $\mathrm{Fe}^{3+}$ and $\mathrm{Co}^{2+}$ species, respectively, anchored to the SBA-15 support; $\mathrm{MS}-\mathrm{FeOH}^{2+}, \mathrm{MS}-\mathrm{CoOH}^{+}$, MS- $\mathrm{CoO}^{+}$, and $\mathrm{RhB}-\mathrm{SO}_{4}{ }^{--}$represent the reaction intermediates; and $\mathrm{SO}_{4}{ }^{-}{ }^{-}$interface is the generated active radical, which plays a crucial role in $\mathrm{RhB}$ degradation. Catalytic oxidation and adsorption both contribute to $\mathrm{RhB}$ degradation in the CoFe/SBA-15/PMS system.

\subsubsection{Quenching tests}

Quenching tests involving addition of $t$-butyl alcohol (TBA) and ethanol were performed to identify the dominant radical species formed during PMS activation by the catalyst (Table 3). The results show that TBA addition did not greatly hinder RhB degradation, even at high concentrations. This implies that there were almost no hydroxyl radicals $\left(\mathrm{OH}^{\bullet}\right)$. However, with ethanol addition, the degradation efficiency gradually decreased to $63.1 \%$, which is far less than the original value. These results suggest that in the CoFe/SBA-15 and PMS system the active radical species are sulfate radicals $\left(\mathrm{SO}_{4}{ }^{--}\right)$[7].

\subsection{Reusability of CoFe/SBA-15 catalyst}

\subsubsection{Effects of different regeneration techniques}

The reusability of the CoFe/SBA-15 catalyst was evaluated, using 10Co9.5Fe/SBA-15-700 as an example, with PMS as the oxidant. The regenerated $10 \mathrm{Co} 9.5 \mathrm{Fe} / \mathrm{SBA}-15-700$ catalyst was immediately added to the RhB solution to initiate the reaction for each recycling run. Two different regeneration techniques were used. In the first one, the virgin catalyst was wrapped in a polytetrafluoroethylene membrane, which we used in a previous investigation as the wrapper for a powdery catalyst. After the first run, the used catalyst was thoroughly washed with ethanol and distilled water, respectively, and dried at $80^{\circ} \mathrm{C}$ for $2 \mathrm{~h}$ to remove ethanol and water before the next run [30]. The recycling performance of the catalyst regenerated using this method is shown in Fig. 14(a). It shows that RhB degradation and Co leaching decreased from $95 \%$ to $63 \%$ and from $30 \mu \mathrm{g} / \mathrm{L}$ to an undetected level, respectively, in the fourth run. The reduction in RhB degradation can be ascribed to deposition of more carbonaceous intermediates of RhB degradation on the active sites of the catalyst with increasing run number, and the Co leaching decreases because of leaching of loosely bound active species during the initial recycling runs.

The second regeneration technique is as follows. The used catalyst was recovered by magnetic separation, washed with distilled water, dried at room temperature, and calcined at a fixed temperature for a given period of time. Figure 14(b) shows the effects of the regeneration conditions on the catalyst reusability. The figure shows that the catalysts regenerated by calcination maintained high catalytic activities, with $\mathrm{RhB}$ removals exceeding 95\%; this suggests that the carbonaceous intermediates of RhB degradation attached to the active sites of the catalyst can be removed by calcination for 1-3 $\mathrm{h}$ at 400-700 ${ }^{\circ} \mathrm{C}$. Co leaching decreased significantly from 220 to 80
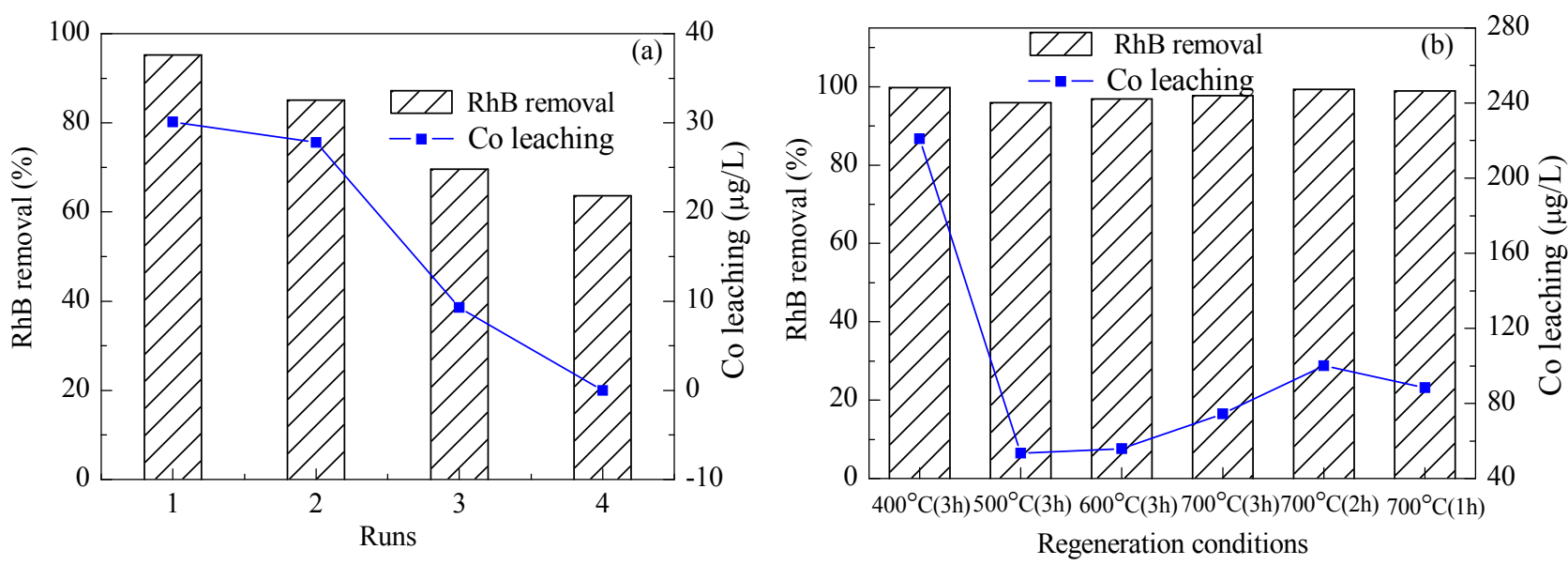

Fig. 14. Effects of different regeneration techniques on recycling performance of $10 \mathrm{Co} 9.5 \mathrm{Fe} / \mathrm{SBA}-15-700$ catalyst. (a) Membrane; (b) Magnetic. Reaction condition: $C_{\mathrm{RhB}} 5.0 \mathrm{mg} / \mathrm{L}, 10 \mathrm{Co} 9.5 \mathrm{Fe} / \mathrm{SBA}-15-700$ 0.10 g/L, PMS/RhB molar ratio $20: 1,25^{\circ} \mathrm{C}, 2 \mathrm{~h}$, no solution pH adjustment. 

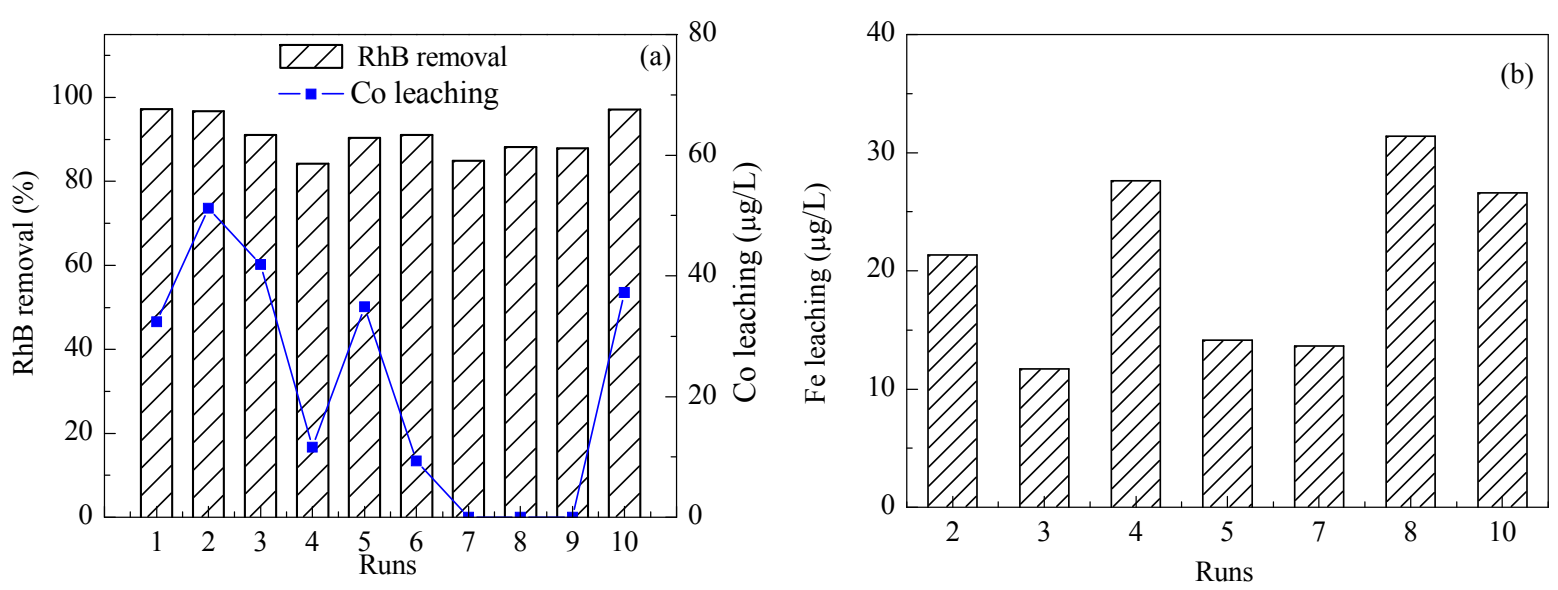

Fig. 15. Recycling performance of $10 \mathrm{Co} 9.5 \mathrm{Fe} / \mathrm{SBA}-15-700$ catalyst. Reaction condition: $C_{\mathrm{RhB}} 5.0 \mathrm{mg} / \mathrm{L}, 10 \mathrm{Co} .5 \mathrm{Fe} / \mathrm{SBA}-15-700$ 0.10 g/L, PMS/RhB molar ratio $20: 1,25^{\circ} \mathrm{C}, 2 \mathrm{~h}$, no solution $\mathrm{pH}$ adjustment.

$\mu \mathrm{g} / \mathrm{L}$ below as the calcination temperature increased from 400 to $500{ }^{\circ} \mathrm{C}$ above, while keeping the calcination tim e at $3 \mathrm{~h}$, and decreased from $100 \mu \mathrm{g} / \mathrm{L}$ to less than $80 \mu \mathrm{g} / \mathrm{L}$ when the calcination time was increased from 1 to $3 \mathrm{~h}$, at $700{ }^{\circ} \mathrm{C}$. A comparison of the various combinations of calcination temperature and time shows that the best combination was calcination at $500{ }^{\circ} \mathrm{C}$ for $3 \mathrm{~h}$. The maximum $\mathrm{RhB}$ degradation, i.e., 95\%, and lowest Co leaching, i.e., $53.5 \mu \mathrm{g} / \mathrm{L}$, were achieved using the catalyst regenerated under these conditions.

\subsubsection{Consecutive reuse of $\mathrm{FeCo} / \mathrm{SBA}-15$ catalyst}

The reusability results for $10 \mathrm{Co} 9.5 \mathrm{Fe} / \mathrm{SBA}-15-700$ are shown in Fig. 15. The used catalyst was regenerated by calcination at $500{ }^{\circ} \mathrm{C}$ for $3 \mathrm{~h}$, based on the test results above. Figure 15(a) shows that the RhB degradation was more than $84 \%$ for 10 consecutive runs; this is attributed to activation of the catalytic sites by effective removal of carbonaceous deposits on the catalyst surface by calcination. The Co leaching remained below $72.1 \mu \mathrm{g} / \mathrm{L}$ (Fig. 15(a)), and Fe leaching was less than $35 \mu \mathrm{g} / \mathrm{L}$ (Fig. 15(b)). These results show the high stability of the 10Co9.5Fe/SBA-15-700 catalyst and the effectiveness of regeneration by calcination. As discussed above, the predominant Co-Fe oxide loaded on SBA-15 was the composite $\mathrm{CoFe}_{2} \mathrm{O}_{4}$, in which the molar ratio of $\mathrm{Co} / \mathrm{Fe}$ is $1: 2$. However, $10 \mathrm{Co} 9.5 \mathrm{Fe} /$ SBA-15 has a 1:1 Co/Fe molar ratio, and the excess Co in 10Co9.5Fe/SBA-15 leads to a higher leaching concentration for Co than for Fe; this is also verified by Fig. 15.

\section{Conclusions}

A heterogeneous catalyst CoFe/SBA-15 was synthesized and characterized. The effects of the CoFe/SBA-15 preparation conditions on the catalytic performance, the kinetics and mechanism of catalytic oxidative degradation of $\mathrm{RhB}$ in the presence of CoFe/SBA-15 and PMS, and the reusability of the catalyst were investigated. The major Co-Fe species loaded on the support was the composite $\mathrm{CoFe}_{2} \mathrm{O}_{4}$, which was present inside and outside the SBA-15 pores, and provided the active sites of the catalyst. 10Co9.5Fe/SBA-15-700 had a smaller sur- face area, pore volume, and pore diameter than SBA-15, and a magnetic intensity of $8.3 \mathrm{emu} / \mathrm{g}$, making it suitable for magnetic separation. It existed in the form of rod-like aggregates of diameter greater than $0.25 \mu \mathrm{m}$. It showed the maximum catalytic activity and stability, giving RhB degradation of more than $96 \%$ and Co leaching of less than $32.4 \mu \mathrm{g} / \mathrm{L}$. The catalytic oxidative degradation of $\mathrm{RhB}$ in the FeCo/SBA-15-PMS system obeyed first-order kinetics, and the degradation rate increased with increasing CoFe/SBA-15 and PMS dosages, and with decreasing initial reactant concentrations. CoFe/SBA-15 maintained high catalytic activity and good stability during 10 recycling runs, with RhB degradation greater than $84 \%$, Co leaching less than $72.1 \mu \mathrm{g} / \mathrm{L}$, and Fe leaching less than $35 \mu \mathrm{g} / \mathrm{L}$ being achieved for each run. CoFe/SBA-15 combined with PMS has promising potential applications in removing non-biodegradable organics such as RhB in water.

\section{References}

[1] Malato S, Blanco J, Richter C, Braun B, Maldonado M I. Appl Catal B, 1998, 17: 347

[2] Chamarro E, Marco A, Esplugas S. Water Res, 2001, 35: 1047

[3] Anipsitakis G P, Dionysiou D D. Environ Sci Technol, 2003, 37: 4790

[4] Cheng M M, Ma W H, Li J, Huang Y P, Zhao J C, Wen Y X, Xu Y M. Environ Sci Technol, 2004, 38: 1569

[5] Chen X Y, Chen J W, Qiao X L, Wang D G, Cai X Y. Appl Catal B, 2008, 80: 116

[6] Neta P, Huie R E, Ross A B. J Phys Chem Ref Data, 1988, 17: 1027

[7] Anipsitakis G P, Dionysiou D D. Environ Sci Techol, 2004, 38: 3705

[8] Anipsitakis G P, Stathatos E, Dionysiou D D. J Phys Chem B, 2005, 109: 13052

[9] Chan K H, Chu W. Water Res, 2009, 43: 2513

[10] Yang Q J, Choi H, Al-Abed S R, Dionysiou D D. Appl Catal B, 2009, 88: 462

[11] Ding Y B, Zhu L H, Huang A Z, Zhao X R, Zhang X Y, Tang H Q. Catal Sci Technol, 2012, 2: 1977

[12] Su S N, Guo W L, Leng Y Q, Yi C L, Ma Z N. J Hazard Mater, 2013, 244-245: 736

[13] Yang Q J, Choi H, Dionysiou D D. Appl Catal B, 2007, 74: 170

[14] Yang Q J, Choi H, Chen Y J, Dionysiou D D. Appl Catal B, 2008, 77: 


\title{
Graphical Abstract
}

Chin. J. Catal., 2015, 36: 1785-1797 doi: 10.1016/S1872-2067(15)60939-1

CoFe/SBA-15 catalyst coupled with peroxymonosulphate for the heterogeneous catalytic degradation of dye rhodamine $B$ in water

Longxing $\mathrm{Hu}^{*}$, Fan Yang, Lianpei Zou, Hang Yuan, Xing Hu Shanghai University

Rhodamine B (RhB) in solution was adsorbed by CoFe/SBA-15 that activated PMS; $\mathrm{Co}^{2+}$ contributed to electron transfer and the sulfate radicals produced attacked the RhB molecules.

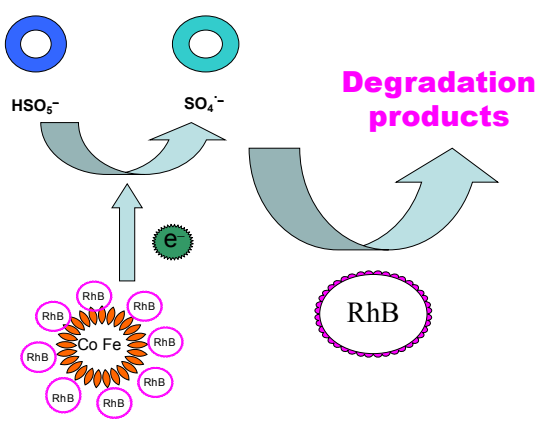

300

[15] Zhang W, Tay H L, Lim S S, Wang Y S, Zhong Z Y, Xu R. Appl Catal B, 2010, 95: 93

[16] Shukla P, Sun H Q, Wang S B, Ang H M, Tadé M O. Sep Purif Technol, 2011, 77: 230

[17] Liang H W, Ting Y Y, Sun H Q Ang H M, Tadé M O.J Colloid Interf Sci, 2012, 372: 58

[18] Zhu Y Q, Chen S, Quan X, Zhang Y B. RSC Adv, 2013, 3: 520

[19] Shukla P R, Wang S B, Sun H Q, Ang H M, Tadé M. Appl Catal B, 2010, 100: 529

[20] Hardjono Y, Sun H Q, Tian H Y, Buckley C E, Wang S B. Chem Eng J, 2011, 174: 376

[21] Sun H Q, Tian H Y, Hardjono Y, Buckley C E, Wang S B. Catal Toady 2012, 186: 63

[22] Yao Y J, Yang Z H, Zhang D W, Peng W C, Sun H Q Wang S B. Ind Eng Chem Res, 2012, 51: 6044

[23] Shi P H, Su R J, Wan F Z, Zhu M C, Li D X, Xu S H. Appl Catal B, 2012, 123-124: 265

[24] Shi P H, Su R J, Zhu S B, Zhu M C, Li D X, Xu S H. J Hazard Mater, 2012, 229-230: 331

[25] Shukla P, Wang S B, Singh K, Ang H M, Tadé M O. Appl Catal B, 2010, 99: 163

[26] Chu W, Choy W K, Kwan C Y. J Agr Food Chem, 2007, 55: 5708

[27] Saputra E, Muhammad S, Sun H Q, Ang H M, Tadé M O, Wang S B. Catal Toady, 2012, 190: 68

[28] Hu L X, Yang X P, Dang S T. Appl Catal B, 2011, 102: 19

[29] Shukla P, Sun H Q Wang S B, Ang H M, Tadé M O. Catal Toady, 2011, 175: 380

[30] Hu L X, Yang F, Lu W C, Hao Y, Yuan H. Appl Catal B, 2013, 134-135: 7

[31] Liang H W, Sun H Q, Patel A, Shukla P, Zhu Z H, Wang S B. Appl
Catal B, 2012, 127: 330

[32] Qi F, Chu W, Xu B B. Appl Catal B, 2013, 134-135: 324

[33] Zhao D Y, Huo Q S, Feng J L, Chmelka B F, Stucky G D. J Am Chem Soc, 1998, 120: 6024

[34] Jun S, Joo S H, Ryoo R, Kruk M, Jaroniec M, Liu Z, Ohsuna T, Terasaki 0. J Am Chem Soc, 2000, 122: 10712

[35] Wang Y R, Chu W. Ind Eng Chem Res, 2011, 50: 8734

[36] Martí nez-de la Cruz A, García Pé rez U M. Mater Res Bull, 2010, 45: 135

[37] Hou M F, Liao L, Zhang W D, Tang X Y, Wan H F, Yin G C. Chemosphere, 2011, 83: 1279

[38] Merouani S, Hamdaoui O, Saoudi F, Chiha M. Chem Eng J, 2010, 158: 550

[39] Bai C P, Xiong X F, Gong W Q, Feng D X, Xian M, Ge Z X, Xu N. Desalination, 2011, 278: 84

[40] Du L, Wu J, Hu C W, Electrochim Acta, 2012, 68: 69

[41] Marler B, Oberhagemann U, Vortmann S, Gies H. Microporous Mater, 1996, 6: 375

[42] Kim S J, Lee S W, An S Y, Kim C S. J Magn Magn Mater, 2000, 215-216: 210

[43] Melero J A, Calleja G, Martínez F, Molina R, Pariente M I. Chem Eng J, 2007, 131: 245

[44] Liang H W, Sun H Q, Patel A, Shukla P, Zhu Z H, Wang S B. Appl Catal B, 2012, 127: 330

[45] Ramirez J H, Maldonado-Hódar F J, Pérez-Cadenas A F, Moreno-Castilla C, Costa C A, Madeira L M. Appl Catal B, 2007, 75: 312

[46] Anipsitakis G P, Dionysiou D D, Gonzalez M A. Environ Sci Technol, 2006, 40: 1000

[47] Wu T X, Liu G M, Zhao J C, Hidaka H, Serpone N.J Phys Chem B, 1998, 102: 5845

[48] He Z, Yang S G, Ju Y M, Sun C. J Environ Sci, 2009, 21: 268

\section{Co-Fe/SBA-15与过一硫酸盐联用非均相催化降解水中染料罗丹明B}

\author{
胡龙兴*, 杨帆, 邹联沛, 袁 航, 胡星 \\ 上海大学环境与化学工程学院, 上海 200444
}

摘要: 由于硫酸根自由基 $\left(\mathrm{SO}_{4}{ }^{-}\right)$的强氧化性,基于 $\mathrm{SO}_{4}{ }^{-}$的高级氧化技术受到人们的高度关注. 采用过渡金属活化过一硫酸盐 $(\mathrm{PMS})$ 产生 $\mathrm{SO}_{4}^{-}$-用以分解有机物, 反应体系简单, 反应条件温和, 且不需要额外的能量供给, 因此, 成为人们优先选用的方法, 其中, 采用高效、环境友好的非均相过渡金属催化剂活化PMS处理难降解有机物成为研究热点. 本文研究了非均相CoFe/SBA-15-PMS 体系对水中难降解染料罗丹明 $\mathrm{B}(\mathrm{RhB})$ 的降解. 以SBA-15为载体, $\mathrm{Co}\left(\mathrm{NO}_{3}\right)_{2} \cdot 6 \mathrm{H}_{2} \mathrm{O}$ 和 $\mathrm{Fe}\left(\mathrm{NO}_{3}\right)_{3} \cdot 9 \mathrm{H}_{2} \mathrm{O}$ 为前驱物, 采用一步等体积浸渍 法制备了 $\mathrm{CoFe} / \mathrm{SBA}-15$, 通过 X射线衍射(XRD)、 $\mathrm{N}_{2}$ 吸附-脱附、扫描电镜(SEM)、能谱(EDS)、透射电镜(TEM)和振动样品磁强计 (VSM)等对其进行了表征. 考察了焙烧温度、Co与Fe的负载量对 $\mathrm{CoFe} / \mathrm{SBA}-15$ 催化性能的影响和该催化剂的重复使用性能, 还考察 
了 $\mathrm{RhB}$ 降解动力学及催化剂 $\mathrm{CoFe} / \mathrm{SBA}-15$ 投加量、氧化剂PMS投加量和反应物(RhB和PMS)初始浓度对其性能的影响, 探讨了 RhB 的降解机理. 结果表明: 对于催化剂 $\mathrm{CoFe} / \mathrm{SBA}-15$, 合成焙烧后在SBA-15上负载的 $\mathrm{Fe} 、 \mathrm{Co}$ 化合物主要是 $\mathrm{CoFe}_{2} \mathrm{O}_{4}$ 复合物, 它作为催化 剂的活性中心负载在SBA-15的孔道内外. 制备的焙烧温度对CoFe/SBA-15催化性能几乎无影响, 但对Co浸出影响显著. 与SBA-15 相比, 催化剂 $10 \mathrm{Co} 0.5 \mathrm{Fe} / \mathrm{SBA}-15-700$ ( Co 和 Fe负载量分别为 $10 \mathrm{wt} \%$ 和 $9.5 \mathrm{wt} \%$, 焙烧温度 $700{ }^{\circ} \mathrm{C}$ )的比表面积、孔体积和孔径均减小, 分别为 $506.1 \mathrm{~m}^{2} / \mathrm{g}, 0.669 \mathrm{~cm}^{3} / \mathrm{g}$ 和 $7.4 \mathrm{~nm}$, 但仍然保持SBA-15的有序六方介孔结构. 该催化剂以棒状体的聚集态存在, 聚集体直径大 于 $0.25 \mu \mathrm{m}$, 其磁化强度为 $8.3 \mathrm{emu} / \mathrm{g}$, 因此, 可通过外磁铁容易地从水中分离. 相比之下, $10 \mathrm{Co} 9.5 \mathrm{Fe} / \mathrm{SBA}-15-700$ 具有最佳的催化性能 和稳定性, 可使 RhB的降解率达到 $96 \%$ 以上, Co的浸出量小于 $32.4 \mu \mathrm{g} / \mathrm{L}$. 在CoFe $/ \mathrm{SBA}-15$ 和PMS共存下, RhB的降解符合一级动力学 方程, RhB 降解速率随 CoFe/SBA-15和PMS投加量的增加和初始反应物浓度的减小而提高. 淬灭实验结果表明, 在CoFe/SBA-15, $\mathrm{PMS}$ 和 $\mathrm{RhB}$ 水溶液体系中, 存在的主要活性自由基为 $\mathrm{SO}_{4}^{-}$, 它是由 $\mathrm{CoFe} / \mathrm{SBA}-15$ 活化PMS产生的, 对 $\mathrm{RhB}$ 的降解起决定性的作用. $\mathrm{RhB}$ 降解过程的UV-vis结果表明, RhB的降解途径主要是葱环打开, $\mathrm{SO}_{4}{ }^{-}$优先攻击RhB的有色芳香烃环, 然后RhB进一步分解为小 分子有机物. $\mathrm{CoFe} / \mathrm{SBA}-15$ 循环使用 10 次仍能保持高催化活性和稳定性, 在每次反应中 $\mathrm{RhB}$ 的降解率均大于 $84 \%, \mathrm{Co}$ 和 $\mathrm{Fe}$ 的浸出量 均分别小于 72.1 和 $35 \mu \mathrm{g} / \mathrm{L}$. CoFe/SBA-15作为高效、环境友好的非均相催化剂可有效地活化 $\mathrm{PMS}$ 产生 $\mathrm{SO}_{4}{ }^{-}$降解水中 $\mathrm{RhB}$, 具有实际 应用的潜力.

关键词: 钴; 铁; SBA-15; 过一硫酸盐; 罗丹明B降解, 高级氧化技术, 硫酸根自由基

收稿日期: 2015-05-18. 接受日期: 2015-06-17. 出版日期: 2015-10-20.

*通讯联系人. 电话/传真: (021)66137771; 电子信箱: hulxhhhb@shu.edu.cn

基金来源：大学创新研究团队项目(IRT 13078).

本文的英文电子版由Elsevier出版社在ScienceDirect上出版(http://www.sciencedirect.com/science/journal/18722067). 